\title{
PROTECTING POST-MORTEM PRIVACY: RECONSIDERING THE PRIVACY INTERESTS OF THE DECEASED IN A DIGITAL WORLD•
}

\author{
LILIAN EDWARDS AND EDINA HARBINJA*
}

INTRODUCTION 102

I. Digital AsSets. 104

II. Digital INTERMEDIARIES: REgULATION OF POST-MORTEM

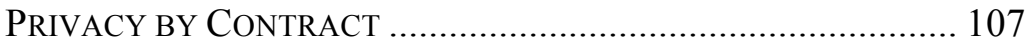

III. PRACTICE AND “LAW” OF DigITAL INTERMEDIARIES

CONCERNING POST-MORTEM PRIVACY .................................. 113

IV. Regulation OF POSt-MORTEM PRIVACy Other THAN BY

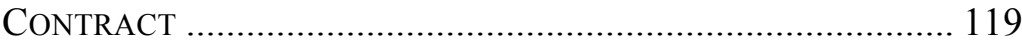

A. Personality, Privacy and Persona Post-Mortem Rights .. 120

1. Common Law 120

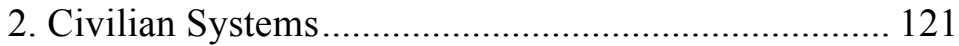

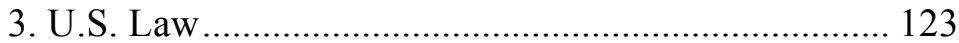

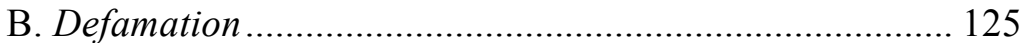

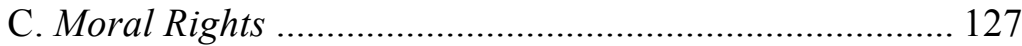

D. Data Protection ................................................................ 130

E. Freedom of Testation ..................................................... 133

V. Situating Post-Mortem Privacy In the Digital Assets

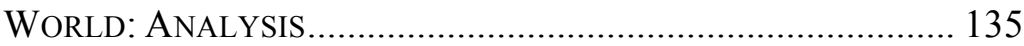

A. Arguments for Post-Mortem Privacy ............................... 135

B. Legal Analysis of Part V ............................................ 137

C. Against Post-Mortem Privacy: The Organ Donation

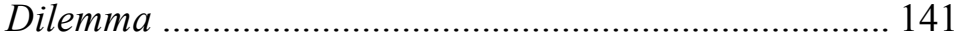

CONCLUSIONS AND NEXT STEPS ................................................ 144

- Permission is hereby granted for noncommercial reproduction of this Article in whole or in part for education or research purposes, including the making of multiple copies for classroom use, subject only to the condition that the name of the author, a complete citation, and this copyright notice and grant of permission be included in all copies.

* Respectively, Professor of Internet Governance, University of Strathclyde, Glasgow; PhD candidate, University of Strathclyde. Ms. Harbinja's research is funded by the Horizon Digital Economy Hub, Nottingham - for which both authors express their gratitude-and forms part of the work programme of the Research Councils UK-funded Centre for Creativity, Regulation, Enterprise and Technology (CREATe). See CREATE, http://www.create.ac.uk (last visited Sept. 9, 2013). (C) 2013 Lilian Edwards and Edina Harbinja. 


\section{INTRODUCTION}

\section{Consider the following hypothetical scenarios ${ }^{1}$ :}

A young U.S. marine dies in combat in Iraq. His widow and heir petitions to have access to his webmail account, but the webmail provider stands by its terms and conditions, which forbid the transfer of account passwords and require termination of the account and deletion of its contents on notice of an accountholder's death. The webmail provider agrees, however, after a court order is obtained, to transfer the contents of the inbox and folders to the widow as a digital download without handing over passwords. On examination, the widow finds to her distress that the e-mails provide evidence of a homosexual affair that the marine was having with a fellow soldier; some of the e-mails say explicitly that she was never to know about it. $^{2}$

A well-known novelist dies suddenly. During her life, she had made it clear she did not want any unfinished works published on death in case they were sub-standard or revealed secrets she had not yet had a chance to acquire permissions to disclose. She dies having destroyed all paper manuscripts but without having destroyed one novel in progress, which is stored in the cloud on an intermediary host service, CloudDrive. Her will leaves everything to her literary executor, Alice, who is aware of these concerns. Meanwhile, however, her sole child, Ben, persuades CloudDrive, which has no published rules on post-mortem access, to give him access to a download of the unfinished novel, by showing the death certificate and proving his relationship to the deceased as her only child. He then downloads and sells the novel for a large sum to an international publisher. $^{3}$

A teenage girl dies having overdosed on drugs at a party, and her Facebook page becomes a shrine to her memory, with friends leaving notes and sharing pictures and memories of the deceased in the

1 These scenarios are drawn partly from existing case law, and partly from discussions in Dedicated Section on Post-Mortem Privacy. See infra note 3 (case law); Lilian Edwards, Editorial, Post-mortem Privacy, in 10:1 SCRIPTED 1 (2013); Elaine Kasket, Access to the Digital Self in Life and Death: Privacy in the Context of Posthumously Persistent Facebook Profiles, in 10:1 SCRIPTED 7 (2013); Edina Harbinja, Does the EU Data Protection Regime Protect PostMortem Privacy and What Could Be The Potential Alternatives?, in 10:1 SCRIPTED 19 (2013); Damien McCallig, Private But Eventually Public: Why Copyright in Unpublished Works Matters in the Digital Age, in 10:1 SCRIPTED 39 (2013); Jan Bikker, Disaster Victim Identification in the Information Age: The Use Of Personal Data, Post-Mortem Privacy and the Rights of the Victim's Relatives, in 10:1 SCRIPTED 57 (2013).

2 Drawn from the facts of the U.S. case of in re Ellsworth, No. 2005-296, 651-DE (Mich. Prob. Ct. 2005), but with significant changes to the facts. For further explanation, see infra Part III.

3 Compare the case of Nabokov who similarly attempted and failed to prevent the publication of post-mortem works. See Alexis Kirschbaum, The Inside Story of Nabokov's Last Work, GuARDIAN (Nov. 17, 2009, 08:18 AM), http://www.guardian.co.uk/books/2009/nov/17/insidestory-nabokov-last-work. 
comments. When her parents, who are not social media users, are finally alerted to this, they are distressed at some of the posts on the profile relating to drinking and drugs. As nearest family, they ask Facebook to close the page down. ${ }^{4}$ They also ask Facebook to give them access to Friends-locked posts they cannot see, so they can find out who might have encouraged their daughter's lifestyle. ${ }^{5}$ Later, they find pictures of their daughter's unconscious body at the party have leaked on to the Internet and have "gone viral."

These are all scenarios that intuitively concern what we shall call post-mortem privacy: rights of privacy for the dead. Post-mortem privacy is not a recognised term of art or institutional category in general succession law or even privacy literature. It may be termed the right of a person to preserve and control what becomes of his or her reputation, dignity, integrity, secrets or memory after death. While of established concern in disciplines such as psychology, counselling, anthropology and other humanities and social sciences, ${ }^{6}$ this notion has, until recently, received relatively little attention, and then of only a scattered, conflicted and disparate kind, within law. ${ }^{7}$ It is now however emerging, we will argue, as an appropriate topic of public and scholarly legal concern, ${ }^{8}$ particularly due to the growth in creation, sharing and acquisition of digital assets which often have a peculiarly personal and intimate character, and also happen to be voluminous, shareable, hard to destroy and difficult to categorise under current legal norms of property

4 See Kasket, supra note 1; see also Jefferson Puff, Brazil Judge Orders Facebook Memorial Page Removed, BBC NEws (Apr. 24, 2013, 6:03 PM), http://www.bbc.co.uk/news/world-latinamerica-22286569. In this case, a mother successfully petitioned a Brazilian court to order the complete deletion rather than mere memorialisation of a Facebook page of her twenty-four year old deceased daughter. Facebook itself had apparently memorialised the page and refused to take it down completely. The mother told journalists, "[t]his 'wailing wall' just makes me suffer too much." Id. The judge was reported as agreeing that the memorial wall went against "the right of personal dignity" and "inflicted great suffering on the mother." $I d$.

5 This part of the scenario is drawn from the facts (with alterations) of in re Request for Order Requiring Facebook, Inc. to Produce Documents and Things, 923 F. Supp. 2d 1204 (N.D. Cal. 2012).

6 See, e.g., Dying, Death and Grief in an Online Universe (Carla J. Sofka, Kathleen R. Gilbert \& Illene N. Cupit eds., 2012); Brian Carroll \& Katie Landry, Logging on and Letting Out: Using Online Social Networks to Grieve and to Mourn, 30 BULL. SCI., TECH. \& SoC'Y 341 (2010) [hereinafter Logging on and Letting Out]; Dennis Klass, Continuing Conversations About Continuing Bonds, 30 DEATH STUD. 843 (2006).

7 See, e.g., Dedicated Section on Post-Mortem Privacy, supra note 1. Additionally, on October 8, 2012, the Amsterdam Privacy Conference hosted a panel discussion entitled Death and PostMortem Privacy in the Digital Age. For more information, see Conference Programme and Book of Abstracts, APC 2012, http://www.apc2012.org/content/conference-pro-gramme-and-bookabstracts (last visited Sept. 10, 2013).

8 See, e.g., Lilian Edwards \& Edina Harbinja, What Happens to My Facebook Profile When I Die? Legal Issues Around Transmission of Digital Assets on Death, in DigiTAL LEGACY AND InTERACTION: POST-MORTEM ISSUES (Cristiano Maciel \& Vinicius Pereira eds., forthcoming 2013); Jason Mazzone, Facebook's Afterlife, 90 N.C. L. REV. 143 (2012); Deven R. Desai, Property, Persona, and Preservation, 81 TEMP. L. REV. 67 (2008). 
or rights.

As we shall see below, the conventional wisdom, especially in common-law states such as the United States and United Kingdom, is that the law does not protect post-mortem privacy. We shall argue, however, that post-mortem privacy is deserving of post-mortem protection in the changed circumstances of the digital era, and that, while it is currently somewhat protected, that protection lies not in any single overriding principle or legal institution, but rather via a range of legal instruments and institutions, which vary in effect, origin and purpose from legal system to legal system. Legal institutions that can be deployed to protect post-mortem privacy may include the laws of privacy, breach of confidence, intellectual property, personality, publicity, defamation, succession, executry and trusts, and data protection. We outline below the contours of legal protection for persona interests after death, and discuss their drawbacks from a comparative perspective. In particular, as European writers, we draw attention to the lack of protection for a deceased's personal data in terms of the EC Data Protection Directive, even though this is recognised as the principle means of protection of informational privacy in EU member states. We will show that stark disparities in legal protection, actual or potential, arise between civilian and common law jurisdictions, with civilian systems more inclined, as a matter of history and philosophy, to show respect for the dignity, honour and reputation, and hence the privacy, of the dead.

Notwithstanding such general legal protection, however, regulation of both the privacy and property rights of the deceased will often fall in the first instance to be determined by the contractual rules and norms of digital intermediary platforms, such as social networks, where digital assets are most often stored, created or shared. Since the dominant intermediaries in the various Western web 2.0 markets are primarily, though not exclusively, U.S. based, this may negate the sympathetic disposition of civilian systems, leaving poor protection for the postmortem privacy of the deceased in more than just common law countries.

Finally, we will briefly consider what the next steps may be for taking post-mortem privacy more seriously in a digital, globalised and intermediarised world, and ask if breaking privacy into "negative" and "positive" variations might be a way forward.

\section{Digital AsSets}

Within this Article, "digital assets" are defined widely and not exclusively to include a range of intangible information goods associated with the online or digital world, including: social network profiles (on platforms such as Facebook, Twitter, Google+ or 
LinkedIn); e-mails, tweets, databases, etc.; in-game virtual assets (e.g., items bought, found or built in worlds such as Second Life, World of Warcraft, Lineage.); digitised text, image, music or sound (e.g., video, film and e-book files); passwords to various accounts associated with the provision of digital goods and services, either as buyer, user or trader (e.g., to eBay, Amazon, Facebook, YouTube.); domain names; two- or three-dimensional personality-related images or icons (such as user icons on LiveJournal or avatars in Second Life); and the myriad of digital assets emerging as commodities capable of being assigned worth (e.g., "zero day exploits" or bugs in software which antagonists can exploit). ${ }^{9}$

Palfrey and others assert that the growth of the Internet and associated information- and network-technologies has created a tribe of "digital natives," 10 who create, store, share and access an enormous amount of digital assets online daily. Alongside, the number of Internet users worldwide, "born digital" and later arriving, continues to rise, ${ }^{11}$ as much among the "silver surfers" as the youth demographic. ${ }^{12}$ Although not much discussed in the optimistic world of Web 2.0, by nature, a significant number of these living "digital lives" die every day. ${ }^{13}$ Over the last few years, public and media interest in what happens to digital assets after death, and whether the wishes of decedents will have legal affect where they conflict with the wishes of families or platforms, has

9 LILIAN EDWARDS, LAW AND THE INTERNET 687-90 (Lilian Edwards \& Charlotte Waelde eds., 3d ed. 2009).

10 Palfrey and Gasser define digital natives as individuals that satisfy the following criteria: born after 1980, have access to digital technology, and have skills to use digital technology "in relatively advanced ways." See John Palfrey \& Urs Gasser, Reclaiming an Awkward Term: What we Might Learn from "Digital Natives," 7 J.L. \& POL'Y FOR INFO. SOC'Y 33, 37-38 (2011). Cheatham defines digital natives as a generation that has never known a world without digital technologies. See Cheryl Cheatham, Public Relations: Dancing with Digital Natives: A Great Resource for Understanding Those Who Have Grown up with Digital Technology, 16 AM. Ass'N OF L. LIBR. SPECTRUM 8 (2012).

11 For example, as of June 2013, Facebook had 1.15 billion active users worldwide. Newsroom: Key Facts, FACEBOOK, http://newsroom.fb.com/Key-Facts (last visited Sept. 12, 2013).

12 See Kathryn Zickuhr \& Mary Madden, Pew Research Center, Pew Internet \& AMERICAN LIFE PROJECT, OldER ADULTS AND INTERNET USE (2012); Laura Roberts \& Harry Wallop, Silver Surfers Increase by One Million Over the Last Year, THE TELEGRAPH (June 30, 2010, 7:30 AM), http://www.telegraph.co.uk/technology/internet/7862234/Silver-surfersincrease-by-one-million-over-the-last-year.html; Press Release, DB Research, Thomas F. Dapp \& Hannah Berscheid, Silver Surfers: The Importance of Older Generations for the Internet (August 20, 2013).

13 As of March 2012 it was estimated there are at least 30 million profiles on Facebook relating to dead people. See Alicia Eler, "I Wanna Live Forever," or How We Die on Social Networks, READWRITE, (Mar. 6, 2012), http://readwrite.com/2012/03/06/i_wanna_live_forever_or_how_we die on social netwo. Research suggests that approximately 375,000 Facebook users in the United States die every year. Mazzone, supra note 8, at 1647; see also Nathan Lustig, $2.89 \mathrm{~m}$ Facebook Users Will Die in 2012, 580,000 in the USA, NATHANLUSTIG.COM (June 6, 2012), $\mathrm{http} / /$ www.nathanlustig.com/2012/06/06/2-89m-facebook-users-will-die-in-2012-580000-in-theusa/. 
slowly risen and become widespread. ${ }^{14}$

In emerging legal discourse, disputes over digital assets on death can be usefully divided as related either to their pure economic value, or to their non-economic value (what might be called their dignitary or personal value). Domain names, for example, are obvious economic assets that may be crucial to the branding and thus the profitability of a business. In a family business, not only who inherits the domain name itself, but also who gets the e-mail notification of the upcoming need to re-register, may be controversial issues. Similarly, many outlet businesses nowadays operate exclusively on eBay and, again, who inherits that account (i.e., the password and login), the money attached to the account, and any connected on-going auctions will be a serious matter. Virtual assets in game worlds often represent the fruit of thousands of hours of labour (if game playing can be called labour) ${ }^{15}$ and there is already a substantial amount of ethical and legal literature regarding their value, sale and the conditions required for transferability. ${ }^{16}$ Photos, blogs and text (i.e., spontaneous poems) shared on a celebrity's social network profile - or those who die and later become famous - are likely soon to be of economic value, just as an

14 For a random selection from an enormous grey literature, see Jessica Hopper, Digital Afterlife: What happens to your online accounts when you die?, NBCNEWS (June 1, 2012), http:// rockcenter.nbcnews.com/_news/2012/06/01/11995859-digital-afterlife-what-happens-to-youronline-accounts-when-you-die?lite; Evan Carroll, What Happens to Your Facebook Account When You Die? THE Digital BeYOND (Feb. 7, 2012), http://www.thedigitalbeyond.com/ 2012/02/what-happens-to-your-facebook-account-when-you-die/; Jagat Shah, Digital Life After Death: America One Step Ahead. On Your Passing, Your Online Presence Will Remain. But Should It?, MORRISONS SOLICITORS (Feb. 22, 2012), http://www.morrlaw.com/news/digital-lifeafter-death-america-one-step-ahead; Rebecca Herold, How to Protect Your Privacy After You Die, INFOSEC ISLAND (Apr. 6, 2010), http://www.infosecisland.com/blogview/3537-How-toProtect-Your-Privacy-After-You-Die.html; Naomi Cahn, Postmortem Life On-line, ProB. \& Prop., July/August 2011, at 36; Lisa Foy, Is There Life After Death for Your Digital Assets?, JDSUPRA LAW NEWS (Mar. 19, 2013), http://www.jdsupra.com/legalnews/is-there-life-afterdeath-for-your-digit-97080/ ("Digital assets. It is a phrase that is currently trending among legal commentators and Canadians alike.").

15 Playing games as piecework to create commercially transferable assets (or levels of play) is often called gold-farming, and usually done by developing world players on low wages to sell to time-poor developed world players. See Julian Dibbell, The Life of a Chinese Goldfarmer, N.Y. TIMES MAG. (June 17, 2007), http://www.nytimes.com/2007/06/17/magazine/17lootfarmerst.html? r $=0$.

16 See, e.g., Edward Castronova, Virtual Worlds: A First-Hand Account of Market and Society on the Cyberian Frontier (CESifo Working Paper Series No. 618, 2001), available at http://ssrn.com/abstract=294828; Joshua A.T. Fairfield, Virtual Property, 85 B.U. L. REV. 1047 (2005); Charles Blazer, The Five Indicia of Virtual Property, 5 PIERCE L. REV. 137 (2006); Gregory Lastowka \& Dan Hunter, The Laws of the Virtual Worlds, 92 CAL. L. REV. 1 (2004); Richard Heeks, Understanding "Gold Farming” and Real-Money Trading as the Intersection of Real and Virtual Economies Virtual Economies, Virtual Goods and Service Delivery, J. VIRTUAL WORLDS RES. (Feb. 2010), http://journals.tdl.org/jvwr/index.php/jvwr/article/view/868/633; Theodore J. Westbrook, Owned: Finding a Place for Virtual World Property Rights, Mich. ST. L. REV. 779 (2006); Ryan Vacca, Viewing Virtual Property Ownership Through the Lens of Innovation, 76 TENN. L. REV. 33 (2008). 
author's letters and unpublished novels ${ }^{17}$ may be of value today.

But such assets may also be of what one might call dignitary or personal value. Millions of photos exist on Flickr, Picasa, etc., which are of very little value to anyone but the accountholder's immediate friends and family - but to them they may be priceless. Similarly, access to the e-mails of a deceased family member may be of utmost importance to the bereaved, and this issue more than any has sparked public and legislative attention to the subject of digital assets, intermediary platforms and death. ${ }^{18}$ Another crucial modern phenomenon is the trend towards "memorialisation" of social network profiles on Facebook and the like; 19 effectively turning them into shrines to the memory of the deceased, where friends leave last messages and other friends gather to read them. ${ }^{20}$ In such cases, although money is not (usually) the issue, emotions can run very high and conflicts develop: Do the friends or the parents decide if the profile is memorialised? What if the profile tells people something about the deceased the parents would rather suppress (e.g., homosexuality, atheism, suicide)? The increasing relevance of issues such as these has started to reach the courts: the first litigation relating to access to, and possession of, social network profiles is also beginning to percolate through. ${ }^{21}$

\section{Digital InTERmediaries: Regulation of Post-Mortem PRIVACY BY CONTRACT}

Crucially, many important digital assets are controlled, both

\footnotetext{
17 See, e.g., Kirschbaum, supra note 3; see also Charlotte Bronte Letters Sell for \$296,000, MSN NEwS (Dec. 13, 2012), http://news.msn.com/pop-culture/charlotte-bronte-letters-sell-fordollar296000-2 (reporting the sale of six letters written by Charlotte Bronte for nearly $\$ 300,000$ and the sale of a her previously unpublished novel for $\$ 1.1$ million in 2011).

18 See supra Scenario 0; see also infra Parts III and IV.

19 See supra Scenario 0. "Memorialisation" usually involves freezing all posts at time of death, preventing adding of any new Friends and rejecting further login attempts, but allowing existing Friends of the deceased to add comments. See, e.g., Elaine Kasket, Continuing Bonds in the Age of Social Networking, 31(2) BerEAVEMENT CARE 62 (2012); Patrick Stokes, Ghosts in the Machine: Do the Dead Live on in Facebook?, 25 PHIL. \& TECH. 363 (2012).

20 See Carroll \& Landry, supra note 6, at 341-49; Kimberly Hieftje, The Role of Social Networking Sites in Memorialization of College Students, in DYING, DEATH AND GRIEF IN AN ONLINE UNIVERSE, supra note 6, at 31-46.

21 See, e.g., in re Request for Order Requiring Facebook, Inc. to Produce Documents and Things, 923 F. Supp. 2d 1204 (N.D. Cal. 2012); Puff, supra note 4 (discussing a Brazilian case involving the Facebook page of a deceased girl). See also Nebraska is Latest State to Address Digital Legacy, DEATHANDDigitAlLEGACY.COM, (Feb. 20, 2012), http://www.deathanddigitallegacy .com/2012/02/20/nebraska-is-latest-state-to-address-digital-legacy/ (discussing the Janna Moore Morin case involving a conflict between family and friends over whether Facebook page should be deleted or memorialised); Video: Interview With the Family of Janna Moore Morin, Living Online After Death Faces Nebraska Legal Battle, BBC NEWS (Jan. 31, 2012), http:// www.bbc.co.uk/news/magazine-16801154. See generally Mazzone, supra note 8. Note that death is likely not to be the only occasion when control of digital assets will come into dispute: divorce and bankruptcy are two other obvious times of conflict.
} 
practically and legally, by digital intermediaries - companies such as Google, Facebook, eBay, Twitter, Flickr, Vimeo, Tumblr, Yahoo! Mail, Hotmail, Blizzard (World of Warcraft), etc. Some non-digital assets are also controlled by intermediaries in the offline world. For instance, sometimes access to a bank account is controlled by the bank when the bank user dies. However, the issue is much more prevalent in the online world.

Access to Facebook profiles, for example, is entirely restricted to those in contractual relationships with Facebook. A user cannot set up a profile, nor read other profiles, without entering into a contract which empowers Facebook to prescribe user conduct on their platform and, inter alia, allocate themselves a non-exclusive license to any works created on the platform.22 Such agreements-whether known as "end user license agreements" ("EULAs") 23 ; terms and conditions ("T\&C"); or Acceptable Use, User or Privacy Policies - are all basically legal contracts. In normal adhesion-contract style, a user is typically deemed, at least in common law systems, to have read and accepted the terms and conditions set by Facebook (or another platform) by indicating acceptance (e.g., clicking an "I accept" button). This remains true even though research shows that most users either do not read or do not understand the privacy policies and do not have any effective ability either to renegotiate the terms or, in many cases, to go to a competitor platform due to the operation of network effect within an oligopolistic market. ${ }^{24}$

When a Facebook user dies, even though their subscriber contract terminates, control of, and access to, the profile remains in the hands of Facebook. Facebook alone has the technical means to close, delete or memorialise the profile, according to its own internal rules or norms, while the heirs of the deceased may not even be able to read the profile if they are not Facebook users, or even if they are, if they were not "Friends" with the deceased (and how many young people have their mother, say, as a "Friend" on Facebook?). ${ }^{25}$ For Facebook users then, control over, and ownership of, the digital assets they create on the Facebook platform-posts, photos, tags, "likes"-is thus primarily regulated by contract. Intermediary contracts often do not contain any explicit rules on what happens to assets stored or created on their platforms upon death. Facebook does give some insight into their

22 See infra note 65.

23 EULAs are common in game and virtual worlds.

24 For an in-depth discussion of this issue, see Lilian Edwards, Privacy, Law, Code and Social Networking Sites, in RESEARCH HANDBOOK ON GOvERnANCE OF THE INTERNET (Brown ed., 2013).

25 For some amusing commentary from young people regarding parental Facebook use, see $\mathrm{OH}$ CRAP. MY PARENTS JOINED FACEBOOK, http://myparentsjoinedfacebook.tumblr.com/ (last visited Sept. 13, 2013). 
internal rules, ${ }^{26}$ but many service provider contracts are simply blank on the matter of death and succession, ${ }^{27}$ which may mean disputes are left to the discretion of abuse teams, or the like. Even where rules do exist though, there is a patent potential for conflict on death between the rules of contract and the rules of succession/executry, as well as between the wishes of the deceased and the wishes of the survivors. This major problem was first explored judicially in the celebrated case in re Ellsworth. ${ }^{28}$

In the landmark Ellsworth case, Yahoo!, a webmail provider, initially refused to give the surviving family of a U.S. marine who was killed in action the log-in rights to his e-mail account. ${ }^{29}$ They pled that their terms of service (i.e. the subscriber contract) forbade transfer of details to third parties on death, and which Yahoo! claimed were designed to protect the privacy of the account owner. ${ }^{30}$ The family argued that as his heirs, they should be able to see his e-mails-his "last words" - and sought access not only to those e-mails sent to them, but also to those sent by the deceased to others, and to those sent by others to the deceased. There was a serious imminent danger that the e-mails would be lost forever if Yahoo!, according to its non-survivorship policy, deleted the account. The judge, in a judgment of Solomon, allowed Yahoo! to abide by its privacy policy, in that the judge did not order transfer of log-in and password information, but rather, ordered Yahoo! to enable access to the deceased's account by providing the family with a CD containing copies of the e-mails in the account. Yahoo!, it seems, also provided a paper copy. ${ }^{31}$

Most of the copious commentary on the Yahoo! case, both journalistic and academic, ${ }^{32}$ has assumed a priori that the family had

26 See infra Figure 1.

27 Laurence Eastham, Funeral Music, SOC'Y FOR COMPUTERS \& LAW BLOG (Feb. 10, 2012), http://www.scl.org/site.aspx?i=bp24899 (noting that the iTunes contract's only mention of death is in relation to exclusion of liability).

28 In re Ellsworth, No. 2005-296, 651-DE (Mich. Prob. Ct. 2005)

${ }^{29}$ Id.; see also Tresa Baldas, Slain Soldier's E-mail Spurs Legal Debate: Ownership of Deceased's Messages at Crux of Issue, 27 NAT'L L.J. 10, 10 (2005).

30 The terms read:

No Right of Survivorship and Non-Transferability. You agree that your Yahoo account is non-transferable and any rights to your Yahoo ID or contents within your account terminate upon your death. Upon receipt of a copy of a death certificate, your account may be terminated and all contents therein permanently deleted.

Yahoo Terms of Service, YAHOO!, http://info.yahoo.com/legal/us/yahoo/utos/terms/ (last visited Sept. 13, 2013).

31 See Soldier's Kin to Get Access to His Emails, JustinEllswORTH.NET (Apr. 21, 2005), http://www.justinellsworth.net/email/ap-apr05.htm. Note that there seemed to be at least initial dubiety that Yahoo! had in fact transferred all e-mails in the account on to the CD. Id.

32 See, e.g., Jonathan Darrow \& Gerald Ferrera, Who Owns a Decedent's E-Mails: Inheritable Probate Assets or Property of the Network?, 10 N.Y.U. J. LEGIS. \& PUB. POL'Y 281, 308 (2006), available at http://ssrn.com/abstract=1698907; Justin Atwater, Who Owns Email? Do You Have the Right to Decide the Disposition of Your Private Digital Life?, 2006 UTAH L. REV. 397; 
[Vol. 32:1

natural justice on their side and that the court was right to find a way to grant their wishes. Relatively few writers have considered that the privacy interests of the deceased might not be co-existent with the desires of the surviving family in all cases, might not align with the interests of all members of that family, or might not be known at all, necessitating further investigation before disclosure of confidential material. In Scenario 0 above, we altered the facts of Ellsworth to have the dead marine engaged in a covert same-sex affair whose revelation might have a negative impact, both for the reputation of the dead and the welfare of the living. Alternatively, the marine might have been hiding an admission of cowardice under fire, a child born to a person other than his partner or beliefs invidious to the religious beliefs of some of his family or friends. We all say things in e-mail that we do not want, or plan for, certain individuals to ever read. Were the Yahoo! privacy policy drafters wrong in assuming that a subscriber to their webmail service would presumably choose not to have their e-mails passed on after death without express pre-mortem consent? Is it correct instead to assume, as some U.S. states already seem to have, ${ }^{33}$ that heirs or family should naturally take a right to the e-mails and other digital assets of a deceased just as they do to traditional assets forming part of the deceased's estate?

Such scenarios raise a number of key problems both practical and theoretical. First, are the e-mails and other digital assets left by a deceased to be regarded purely through the prism of property, or are they also seen as relevant to non-economic, personal-privacy or personality-interests? We discuss this in detail below at Part V. Second, who is seen as having the most effective right to control digital assets stored or conceived on intermediary platforms? On the one hand, traditional succession and executry law points to the family or heirs, and in the first instance, the executor or administrator who ingathers the estate on their behalf. On the other, in reality, technical control accrues to the intermediary, which has no obvious duties in law to the family or heirs, under either contract or confidence, other than those that are imposed by court order ex post facto. In particular it seems unlikely that an intermediary such as Facebook would be regarded as owing fiduciary

Mazzone, supra note 8; John Connor, Digital Life After Death: The Issue of Planning for a Person's Digital Assets After Death (Texas Tech Law School Research Paper No. 2011-02, Dec. 1, 2010), available at $\mathrm{http} / / / \mathrm{ssrn} . \mathrm{com} / \mathrm{abstract}=1811044$.

33 Five states have already adopted laws mandating disclosure of e-mails and similar communications to administrators of deceased's estates: Conn. Gen. Stat. § 45a-334a; IND. CODE $\S$ 29-1-13-1.1; R.I. GEN. LAWS ch. 33-27; OKLA. STAT. ANN. § 269; IDAHO STAT. § 15-3-715(28) and $\S 15-5-424(3)(\mathrm{z})$. Eighteen were considering enacting similar pieces of legislation as of February 2013. See, e.g., Jim Lamm, February 2013 List of State Laws and Proposals Regarding Fiduciary Access to Digital Property During Incapacity or After Death (Feb. 13, 2013), http://www.digitalpassing.com/2013/02/13/list-state-laws-proposals-fiduciary-access-digitalproperty-incapacity-death/. 
duties to heirs, as an executor or trustee would. In practice, the discretionary attitude ${ }^{34}$ many platforms take with issues of post-mortem data curation, preservation and access to digital assets to heirs after death often smacks more of effective internal management mixed with public relations than the kind of attitude expected of a conventional asset repository such as a bank.

Thirdly and connectedly, what occurs if the "rules" of the intermediary, by contract or internal governance norms, conflict with the general law which may guarantee rights as to post-mortem privacy, or distribution of digital assets after death (e.g., copyright, succession, publicity rights)? Such cases raise patent difficulties. ${ }^{35}$ For example, Facebook's memorialisation request form prescribes an order of priority of relatives making a request for memorialisation ${ }^{36}$ that does not correspond to the order of priority of heirs in intestacy in Scots law ${ }^{37}$ (and, no doubt, in many other legal systems). Indeed, no one system could match the law in every jurisdiction where Facebook has subscribers, yet Facebook purports to apply one set of rules to every jurisdiction where it operates. ${ }^{38}$ While the judgment or "law" of intermediaries can be challenged - as in the Ellsworth case itself-such litigation is, and is likely to remain, exceptional, especially in legal systems outside the United States where consumer litigation is unusual and expensive, and often unaided by class actions or contingency fees, and where civil legal aid is increasingly sparse. ${ }^{39}$ For social networks, another element restricting challenge is that current users of the network may not wish to antagonise the "management" by pursuing litigation against them. For many young adults, expulsion from Facebook is, after all, akin to social death. ${ }^{40}$ Another important point is that interpretation of the language of the subscriber contract, unless challenged in court, is likely to fall to IT workers or administrators in abuse teams ${ }^{41}$ or human

34 See infra Part IV.

35 We leave aside here the matter of jurisdiction and choice of law, which in many cases concerning digital assets may further complicate the picture.

36 See infra Figure 1.

37 See Succession (Scotland) Act 1964.

38 Note the effect of the Canadian Privacy Commissioner Facebook decision, discussed infra note 50, which effectively forced Facebook to make changes to its technical code and contractual conditions worldwide.

39 But see cases cited supra note 21 (relating to access to, and possession of, social network profiles upon death).

40 See, e.g., Danah Boyd \& Alice Marwick, Social Privacy in Networked Publics: Teens' Attitudes, Practices and Strategies (Sept. 22, 2011), http://papers.ssrn.com/sol3/papers.cfm? abstract id=1925128 (presented at Oxford Internet Institute's A Decade in Internet Time: Symposium on the Dynamics of the Internet and Society); Danah Boyd, Facebook and "Radical Transparency,” APOPHENIA (May 14, 2010), http://www.zephoria.org/thoughts/archives/2010/ 05/14/facebook-and-radical-transparency-a-rant.html.

41 Abuse teams are employed by many ISPs and hosting sites, such as social networks, to deal with user reports of the abuse of the platform or service (e.g., its use for libel, upload of obscene materials or harassment). As a result, they often become de facto the first arbiters of how terms of 
resources departments - not to trained lawyers who might read in exceptions or principles informing the exercise of discretion from general law or norms. Writers are divided as to whether even an executry court order, if obtained, would take precedence over the contractual rules of the platform. ${ }^{42}$ The issue is crucial, since in some jurisdictions, accessing an account contrary to the terms of service may be seen as unauthorised access, ${ }^{43}$ hacking or a similar crime ${ }^{44}$

Intermediaries themselves face difficult choices in deciding whether to accede to the wishes of family and heirs relating to postmortem privacy and assets or whether to respect the privacy of the deceased subscriber. In the United States, the 1986 Electronic Communications Privacy Act has recently been interpreted as preventing a service provider from disclosing stored communications unless a court order is made, even to heirs in a post-mortem scenario. ${ }^{45}$ Our Scenario 3 references recent case law on this matter. On December 20, 2008, Sahar Daftary died after falling from the twelfth floor of an apartment building located in Manchester, England. Members of her family disputed that Sahar had committed suicide, and believed that her Facebook account contained critical evidence showing her actual state of mind in the days leading up to her death. Facebook, however, refused to grant access to the account to the family without court authorisation, so the family initiated a request to subpoena the records in the California courts. ${ }^{46}$ The court found that the U.S. Stored Communications $\mathrm{Act}^{47}$ prevented a U.S. service provider from disclosing stored communications in civil proceedings. Interestingly, the court based its judgment explicitly on the privacy protection provided

service, especially "acceptable use policies" may be interpreted. See Abuse Teams, ENISA, http://www.enisa.europa.eu/activities/cert/background/coop/terms-definitions-1/otherteams/abuse-teams (last visited Nov. 8, 2013).

42 Compare Darrow \& Ferrera, supra note 8, at 312 (asserting that digital assets should generally fall into the "gross estate" of a deceased, and therefore be considered "probate assets that [are] subject to the same inheritability rules as other probate assets," but not really attacking head-on the difficulties of a conflict between terms of service and court orders), with Jim Lamm, Planning Ahead for Access to Contents of a Decedent's Online Accounts, Digital Passing Blog (Feb. 9, 2012), http://www.digitalpassing.com/2012/02/09/planning-ahead-access-contents-decedentonline-accounts/ (taking the view that even where an executor has the authority of the court to access the deceased's assets, he still may not be authorised to access said assets if contrary to platform rules).

${ }^{43}$ Compare the Computer Misuse Act 1990, c. 18, § 1 (U.K.), with the Wire and Electronic Comm. Interception and Interception of Oral Comm. Act, 18 U.S.C. $\S \S 2510-2522$ (2012).

4418 U.S.C. $\S 1030(a)(2)$ (2012) (criminalizing intentional unauthorized access of computers under certain circumstances).

45 See Facebook Discovery Case, 923 F. Supp. 2d 1204 (N.D. Cal. 2012) (granting motion to quash); see also Ada Kulesza, What Happens to Your Facebook Account When You Die?, LAWYERS.COM (Feb. 3, 2012), http://blogs.lawyers.com/2012/02/what-happens-to-facebookaccount-when-you-die/

46 Facebook is based in California.

4718 U.S.C. $\S 2701$ (2012). 
by this Act. ${ }^{48}$ In so doing, the court held that the interests protected by the U.S. statute extended to a foreign citizen, as much as to a US citizen. $^{49}$ The court, interestingly, refused to rule on whether Facebook could legitimately disclose the records to the family voluntarily, leaving both the social network and the family in an unfortunate state of uncertainty.

\section{PRACTICE AND “LAW” OF DigITAL INTERMEDIARIES CONCERNING POST-MORTEM PRIVACY}

This brings us to considering the actual practices of important online intermediaries in the digital assets world. What is immediately noticeable is that there is no single model of good practice as to postmortem privacy, or, indeed, post-mortem property. Instead, for consumers there is a confusing jungle of difficult to understand terms and conditions. Facebook, in many ways the industry gold standard, ${ }^{50}$ offers users the option of having their profile deleted ${ }^{51}$ or memorialised after death, ${ }^{52}$ as well as the opportunity to provide a download of the deceased's account if prior consent has been given by the deceased, or if

48 In re Request for Order Requiring Facebook, Inc. to Produce Documents and Things, 923 F. Supp. 2d 1204, 1205-06 (N.D. Cal. 2012) ("Having reviewed the papers and considered the arguments of counsel, IT IS HEREBY ORDERED that Facebook's motion to quash is GRANTED. The case law confirms that civil subpoenas may not compel production of records from providers like Facebook. To rule otherwise would run afoul of the "specific [privacy] interests that the [SCA] seeks to protect." (citing Theofel v. Farley-Jones, 359 F.3d 1066, 1074 (9th Cir. 2004)).

$49 \mathrm{Id}$.

50 Facebook's procedures for deletion and memorialisation of deceased's accounts were improved globally partly as a result of a general intervention by the Canadian Privacy Commissioner, adjudicating on formal complaints made. As a result, memorialisation now involves taking the profile out of public search results and preventing further login attempts (e.g., by scammers or persons with whom the deceased had shared the password). See Facebook Agrees to Address Privacy Commissioner's Concerns, OFFICE OF THE PRIVACY COMM'R OF CAN. (Aug. 27, 2009), http://www.priv.gc.ca/media/nr-c/2009/nr-c_090827_e.asp.

51 The relevant section reads:

We will process certain special requests for verified immediate family members, including requests to remove a loved one's account. This will completely remove the timeline and all associated content from Facebook, so no one can view it. For all special requests, we require verification that you are an immediate family member or executor. Requests will not be processed if we are unable to verify your relationship to the deceased. Examples of documentation that we will accept include:

The deceased's birth certificate.

The deceased's death certificate.

Proof of authority under local law that you are the lawful representative of the deceased or his/her estate.

FACEBOOK HELP CENTER, https://www.facebook.com/help/265593773453448/ (last visited Dec. 28, 2012); see also Deactivating, Deleting \& Memorializing Accounts: "How Do I Report a Deceased Person or an Account That Needs to be Memorialized?," FACEBOOK, https:// www.facebook.com/help/359046244166395/ (last visited Sept. 6, 2013) ("In order to protect the privacy of the deceased person, we cannot provide login information for the account. However, once it has been memorialized, we take measures to secure the account.").

52 See infra Figure 1. 
a court order is made after death, as in, most typically, probate or confirmation, but also possibly where law enforcement agencies become involved. ${ }^{53}$ Facebook, however, still refuses to provide heirs with the login and password information needed to access the account itself. Notably, this advice to heirs or family is not contained within the terms and conditions of the Facebook contract itself, but is rather found in the "Help" section, and therefore is arguably a statement of good practice that is not binding on Facebook or enforceable by families or heirs. It is also somewhat difficult for non-legal users to find.

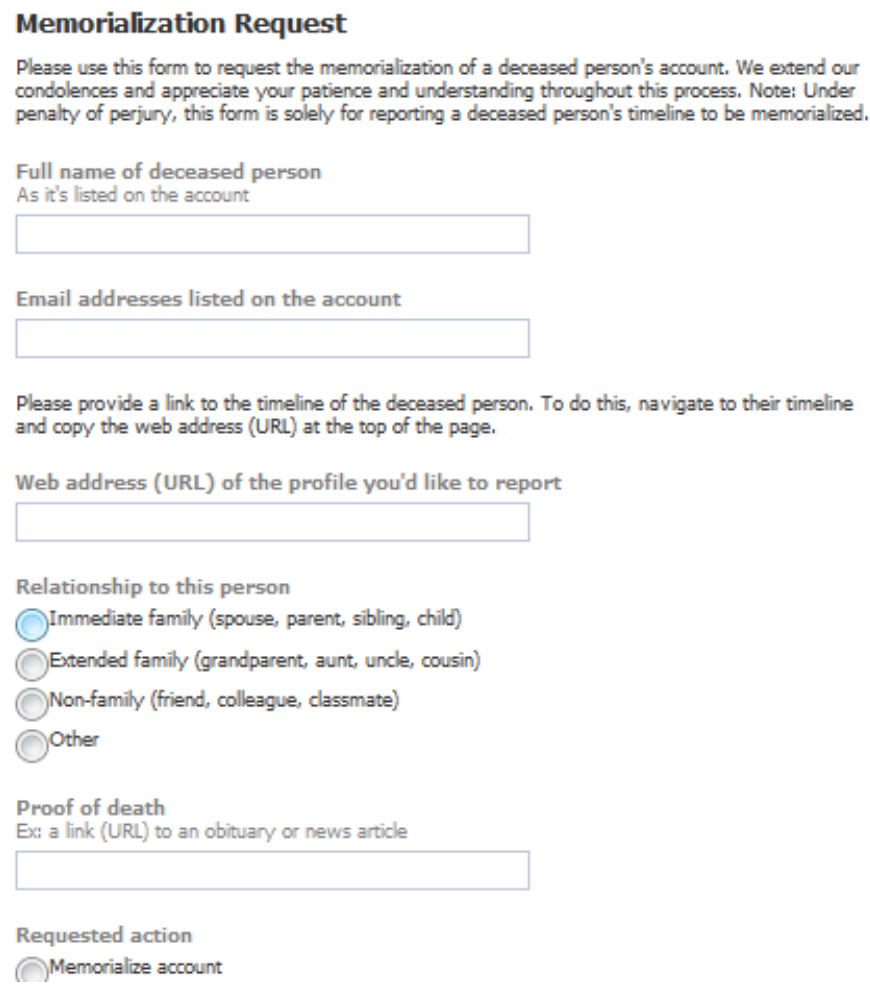

Figure 1: Facebook's Memorialisation Request. ${ }^{54}$

53 Facebook asserts:

We take our responsibility to protect the privacy of people who use Facebook very seriously. We are only able to consider requests for account contents of a deceased person from an authorized representative. The application to obtain account content is a lengthy process and will require you to obtain a court order.

Keep in mind, sending a request or filing the required documentation does not guarantee that we will be able to provide you with the content of the deceased person's account.

Deactivating, Deleting \& Memorializing Accounts: How Do I Request Content from the Account of a Deceased Person?, FACEBOOK, https://www.facebook.com/help/359046244166395/ (last visited Sept. 6, 2013); see also Carroll, supra note 14.

54 FACEBOOK HELP CENTER, https://www.facebook.com/help/contact/?id=305593649477238 
Facebook provides perhaps the most detailed intermediary code on post-mortem remedies. Twitter, by contrast, appears only to allow deactivation of the deceased users account, though some writers report they will also authorise the download of all of a deceased's tweets..$^{55}$ Like Facebook, they explicitly exclude the possibility of providing login information to heirs to access the account of the deceased, leaving only discretionary possibilities of access to the content. ${ }^{56}$

Similarly, as we have seen, Yahoo! (whose policies are also shared by Flickr) also refuses to pass on logins and passwords needed to access accounts to heirs. ${ }^{57}$ Google likewise appears only to contemplate passing on the contents of a Gmail account to the deceased's heirs, rather than passing on login details, and even then the contents will only be given to the heirs in exceptional circumstances. ${ }^{58}$ Microsoft Hotmail, on the other hand, appears willing to offer access to the administrators of estates of incapax, but not deceased, users. ${ }^{59}$ Thus, among webmail providers and social networks, a norm seems to be emerging of allowing discretionary access to content in the accounts of deceased users, but no formal right to such content, and express prohibition of the transfer of account login details. Notably, transfer of account login details would allow family or friends to carry on activities such as posting new content on the site or adding new friends.

Another key contractual area relevant to post-mortem rights, of particular importance in online games or virtual worlds prominently featuring User Generated Content ("UGC"), is the ownership of assets

(last visited Dec. 28 2012).

55 See, e.g., Wendy Moncur, Digital Ownership Across Lifespans, in IUAES Commission on Ageing and the Aged (Chirara Garratini \& David Prendergast eds., Bergahn Books forthcoming 2013).

56 Twitter's policy provides:

In the event of the death of a Twitter user, we can work with a person authorized to act on the behalf of the estate or with a verified immediate family member of the deceased to have an account deactivated. . . . Please note: We are unable to provide login information for the account to anyone regardless of his or her relationship to the deceased.

Help Center: Contacting Twitter About a Deceased User, TwITTER, https://support.twitter.com /groups/33-report-abuse-or-policy-violations/topics/148-policy-information/articles/87894-howto-contact-twitter-about-a-deceased-user (last visited Sept. 6, 2013).

57 See supra Part III; Yahoo! Terms of Service, http://info.yahoo.com/legal/uk/yahoo/utos/en-gb/ (last visited Sept. 6, 2013); in re Ellsworth, No. 2005-296, 651-DE (Mich. Prob. Ct. 2005).

58 With regard to getting access to a deceased's Gmail account, Google's Terms of Service provide:

We extend our condolences for your loss. If you need access to the Gmail account content of an individual who has passed away, in rare cases we may be able to provide the contents of the Gmail account to an authorized representative of the deceased person.

Account Access Issues: Accessing a Deceased Person's Mail, Google, https://support.google .com/mail/answer/14300?hl=en (last visited Sept. 15, 2013).

59 See Mazzone, supra note 8, at 1664 n.98. 
created in these games or via these platforms. As noted above, these assets often have considerable value in the "real world" as well as sentimental value. Blizzard, the World of Warcraft provider, explicitly excludes any property rights of users in assets created or traded in the game and forbids transfers of accounts. ${ }^{60}$ By contrast, Linden Lab, provider of the virtual world Second Life, gives users relatively extensive rights in content created by users therein. ${ }^{61}$ Mazzone notes that in line with these policies, Linden Lab also allows for in-game assets to be transferred and bequeathed on death. ${ }^{62}$ Looking beyond virtual worlds, Instagram, a photo-sharing site recently bought by Facebook, caused Internet protests when, in December 2012, it appeared to change its terms of service to acquire ownership of all user photos stored on the site. Fairly swiftly, the change was reversed. ${ }^{63}$ In

60 Blizzard's terms regarding "Ownership" read:

All rights and title in and to the Service (including without limitation any user accounts, titles, computer code, themes, objects, characters, character names, stories, dialogue, catch phrases, locations, concepts, artwork, animations, sounds, musical compositions, audio-visual effects, methods of operation, moral rights, any related documentation, "applets," transcripts of the chat rooms, character profile information, recordings of games) are owned by Blizzard or its licensors.

World of Warcraft Terms of Use Agreement, BLIZZARD ENTM'T, http:/us.blizzard.com/en-us/ company/legal/wow_tou.html (last updated Aug. 22, 2012). The terms regarding "Ownership/Selling of the Account or Virtual Items" read:

Blizzard does not recognize the transfer of World of Warcraft Accounts or BNET Accounts (each an "Account"). You may not purchase, sell, gift or trade any Account, or offer to purchase, sell, gift or trade any Account, and any such attempt shall be null and void. Blizzard owns, has licensed, or otherwise has rights to all of the content that appears in the Game. You agree that you have no right or title in or to any such content, including without limitation the virtual goods or currency appearing or originating in the Game, or any other attributes associated with any Account. Blizzard does not recognize any purported transfers of virtual property executed outside of the Game, or the purported sale, gift or trade in the "real world" of anything that appears or originates in the Game. Accordingly, you may not sell in-game items or currency for Id. "real" money, or exchange those items or currency for value outside of the Game.

61 Specifically, users retain the title to all intellectual property brought into the game, maintain the right to delete all copies of their content from the game, and most importantly, retain full rights in the content they create. See Linden Lab Terms of Service: 2.1 Linden Lab Owns Intellectual Property Rights in the Service and the Linden Marks, LINDEN LAB, http://lindenlab.com/tos (last visited Sept. 15, 2013) ("You acknowledge and agree that Linden Lab and its' licensors own all right, title, and interest in and to the Service, including all Intellectual Property Rights therein, other than with respect to User Content.") (emphasis added); see also Vacca, supra note 16; Alisa B. Steinberg, For Sale-One Level 5 Barbarian for 94,800 Won: The International Effects of Virtual Property and the Legality of Its Ownership, 37 GA. J. INT'L \& COMP. L. 381 (2009); Jennifer Gong, Defining and Addressing Virtual Property in International Treaties, 17 B.U. J. SCI. \& TECH. L. 101 (2011).

62 Mazzone, supra note 8 (citing Linden Lab Official: Death and Other Worries Outside Second Life, SECOND LIFE WIKI, http://wiki.secondlife.com/wiki/Linden_Lab_Official:Death_and_other_ worries_outside_Second_Life).

63 In any event, the actual legal significance and implications of the change were disputed. See Amanda Holpuch, Instagram Reassures Users Over Terms of Service After Massive Outcry, THE GUARDIAN (Dec. 18, 2012, 6:08 PM), http://www.guardian.co.uk/technology/2012/dec/18/ instagram-issues-statement-terms-of-service. 
fact, Instagram's provisions on ownership ${ }^{64}$ now, unsurprisingly, very closely resemble Facebook' ${ }^{65}$ in that they require the user to grant a non-exclusive, royalty-free license over any content hosted or posted on the service. In practice it is understood that this non-exclusive license is mainly used so that on-site profiles can be displayed in marketing. It is easy to imagine that the privacy interests of a deceased and their surviving family might well be invaded if Facebook, say, used a picture of the deceased smiling happily in their corporate marketing materials. Interestingly, Google, which operates many services allowing the submission of original content (e.g., homemade videos on YouTube, blogs on Blogger, texts stored on Google Drive), explicitly and very plainly disclaims any rights in the intellectual property therein. ${ }^{66}$

Most importantly for this Article, until very recently none of the major social media or hosting platforms offered an easy way for users to express, on the site, in advance of death, their preferences as to what would happen to their digital assets, and by extension, private facts about their life, after they died. Being able to clearly indicate such wishes on the site, and have them respected, is clearly a preferable solution to the problems of post-mortem privacy. Lacking such a facility, a user has few other effective choices. They can trust their wishes to a will, which as discussed above and in Scenario 0, might or might not be given effect by the intermediary, and may invoke executor/platform conflicts. Furthermore, in most countries, rates of intestacy are high, particularly amongst the young, who are not prone to facing up to mortality and making a will. ${ }^{67}$ They can use one of the new

64 See Terms of Use, INSTAGRAM, http://instagram.com/about/legal/terms/\# (last updated Jan. 19, 2013) ("Instagram does not claim ownership of any Content that you post on or through the Service. Instead, you hereby grant to Instagram a non-exclusive, fully paid and royalty-free, transferable, sub-licensable, worldwide license to use the Content that you post on or through the Service ....."). Interestingly, though, Instragram's post-Facebook merger policy on deceased users remains extremely vague by comparison to Facebook's. See Privacy Policy, Rule 8, INSTAGRAM, http://instagram.com/about/legal/privacy/\#section8 (last updated Jan.19, 2013).

65 Facebook's terms read:

[Y]ou grant us a non-exclusive, transferable, sub-licensable, royalty-free, worldwide

license to use any IP content that you post on or in connection with Facebook (IP

License). This IP License ends when you delete your IP content or your account unless

your content has been shared with others, and they have not deleted it ....

Statement Of Rights and Responsibilities, FACEBOOK, https://www.facebook.com/legal/terms (last updated Dec. 11, 2012).

66 See Terms of Service, GoOGLE, http://www.google.com/intl/en/policies/terms/ (last updated March 1, 2012) ("Your content in our services. Some of our Services allow you to submit content. You retain ownership of any intellectual property rights that you hold in that content. In short, what belongs to you stays yours.") (emphasis added). Note that the YouTube terms of service modify this to require the user to grant a license to YouTube. See Terms of Service, Sec. 8, YOUTUBE, http://www.youtube.com/static?template=terms (last updated June 9, 2010).

67 For example, nearly $60 \%$ of adults in England and Wales have not made a will. See Joe Thornhill, Die Intestate and Your Loved Ones Will Be Left to Untangle Your Legacy, MAILONLINE (July 28, 2012, 4:03 PM), http://www.thisismoney.co.uk/money/pensions/article2180242/Die-intestate-loved-ones-left-untangle-legacy.html. 
breeds of "digital will" online services, such as Legacy Locker, but in effect these face the same problems as an actual will, but without the benefit of legal or platform advice. Users would, one imagines, be much more likely to use an on-site facility, which could be as easy to use as clicking on other site settings; moreover, users could then reasonably expect the platform to conform to their wishes, if perhaps still not those of their families or heirs. We have argued in previous work that just as social media sites now generally provide users with privacy preference tools during life, albeit grudgingly and inconstantly, they should also provide them with tools to pre-assign what happens to their personal data when they die. ${ }^{68}$ Until now, however, there was little sign of such a practice emerging, with strong, though unproveable suspicion, that most social networks, curating an environment designed for fun and entertainment, would rather (ahem) bury any mention of death rather than forefront it.

In a radical move forward, however, in April 2013, Google (whose empire includes not just their search engine but also Gmail, Blogger, Picasa and many other host sites for digital assets) introduced the Orwellian sounding "Inactive Account Manager," 69 which allows users to prescribe which of a number of data disposal methods they wish to be pursued after a prescribed length of inactivity (say, one, three or nine months). As Google provides:

You might want your data to be shared with a trusted friend or family member, or, you might want your account to be deleted entirely. There are many situations that might prevent you from accessing or using your Google account. Whatever the reason, we give you the option of deciding what happens to your data. ${ }^{70}$

It will be interesting to see if the other major players follow Google's precedent.

Finally, it is worth noting that the range of stakeholders involved in post-mortem privacy and digital assets cases is by no means limited to platforms, heirs and those in a contractual relationship with service providers. ${ }^{71}$ Society in general, as well as specific heirs, family and friends, have an interest in the legacy of the dead; for example, authors' letters (or e-mails, or blogs) have value to historians, scholars and critics as well as a market value to collectors. McCallig argues interestingly that in the past, copyright acted as a surrogate for post-mortem privacy

68 Edwards \& Harbinja, supra note 8.

69 See Andreas Tuerk, Plan Your Digital Afterlife with Inactive Account Manager, GoogLE PUBLIC POLICY BLOG (Apr. 11, 2013), http://googlepublicpolicy.blogspot.co.uk/2013/04/plan-yourdigital-afterlife-with.html.

70 See Google Inactive Account Manager, https:/www.google.com/settings/u/0/account/ inactive (last visited Apr. 29, 2013).

71 See Desai, supra note 8. 
in such situations by providing that unpublished copyright writings (such as letters or nowadays, arguably, Friends-locked social media profiles) were transferable on death only by express written inter vivos instructions. ${ }^{72}$ In modern copyright law, however, at least in the United Kingdom, Ireland and the United States, such restrictions have, on the whole, disappeared, and unpublished copyright texts will, like other assets in the deceased's estate, transfer automatically to heirs unless deliberately destroyed before death (a process that would have been plausible for hard copy texts (or audio tapes, or recorded video) but is extremely hard to guarantee for digital texts in a world of remote, networked, mirrored and archived storage). We discuss the place of the public interest in assessing the case for post-mortem privacy, below in Part VI.

\section{Regulation of Post-Mortem Privacy Other Than By CONTRACT}

Privacy is often perceived amongst academics as a subset of a general group of rights seen as personal to the deceased, and so named "personality rights."73 As usefully summarised by Whitty and Zimmermann, personality rights may cover at least the following categories of interests: life, bodily integrity, personal security, physical liberty, reputation, dignity, privacy, identity (image), moral rights to copyright, autonomy, family relationships and rights of deceased's relatives. ${ }^{74}$ These categories protect not only the personal attributes of individuals, but often also the economic or patrimonial, as most noticeably in the context of the commercial exploitation of celebrity image rights, and are conceived of very differently in common and civil law systems. ${ }^{75}$ Post-mortem privacy rights will be explored here through the general law around personality rights, in particular focusing on: civilian "personality rights," common law "publicity rights" and privacy torts; defamation; and the moral rights of authors (it is tempting, though provocative, to suspect that a better new term of art to invent than "postmortem privacy" might indeed be "post-mortem personality"). This

\footnotetext{
72 McCallig, supra note 1.

73 From an enormous literature, useful comparative texts on personality rights include: NIAL WHITTY \& REINHARD ZIMMERMAN, RIGHTS OF PERSONALITY IN SCOTS LAW: A COMPARATIVE Perspective (2009); HuW Beverley-SMith, ANSGAR OHLy \& AGNeS LuCAS-SChlOetTer, Privacy, Property AND PERSONALITY: CiVIL LAW PERSPECTIVES ON COMMERCIAL APPROPRIATION (2005); HUW BEVERLEY-SMITH, THE COMMERCIAL APPROPRIATION OF Personality (2002); Gillian Black, Publicity Rights and Image: ExPloitation and Legal Control (2011); Gert Bruggemheier, Aurelia C. Ciacci \& Patrick O'Callaghan, Personality Rights in European Tort laW (2010); J. NeEthling, J.M. Potgieter \& P.J. VisSER, NeETHLing'S LAW OF PERSONALity (1996); CEes VAN DAM, EUROPEAN TORT LAW (2007).

74 Whitty \& Zimmerman, supra note 73, at 3, 165.

75 See id. at $310-11$.
} 
Article will approach this issue comparatively, looking at key civilian and common law jurisdictions with regard to their treatment of postmortem privacy.

\section{A. Personality, Privacy and Persona Post-Mortem Rights}

\section{Common Law}

In the English, U.S., and other common law systems, the reigning principle has traditionally been actio personalis moritur cum persona, meaning personal causes of action die with the person, (e.g., defamation claims, breach of confidence claims, wrongful dismissal claims, etc.). ${ }^{76}$ Although this principle has been whittled away at in many contexts for reasons of social policy such as the need to succour to the dependents of the deceased, ${ }^{77}$ Beverley-Smith, perhaps the leading English writer on commercial image rights, still represents a prevailing sentiment in noting that, "reputation and injured dignity are generally of no concern to a deceased person." 78 By contrast, economic claims traditionally survive death in common law and pass to the heirs in testacy or intestacy. Indeed, the widest and most accepted definition of property (as opposed to personal right) is that which survives and transmits on the death of the proprietor. Reflecting this emphasis on economic rights, the term "personality rights" is itself not recognised as a term of art in common law; ${ }^{79}$ rather, specific torts and causes of action are used to protect certain aspects of personality, including, in various countries, breach of confidence, false endorsement, passing off, malicious falsehood, appropriation of personality, trespass and nuisance. ${ }^{80}$ Most notably, the English courts continue to deny that a distinct tort of invasion of privacy exists ${ }^{81}$ and have no separate category of publicity or image rights as in the U.S., ${ }^{82}$ although the gap has to some extent been taken up by the development of various torts, including breach of

76 See Baker v. Bolton, (1808) 170 Eng. Rep. 1033 (K.B.).

77 The principle has been revised in the United Kingdom and now only pertains to causes of action for defamation and certain claims for bereavement. See generally Law Reform (Miscellaneous Provisions) Act 1934, c. 41 (U.K.), The Race Relations Act 1976, c. 74 (U.K.), Sex Discrimination Act 1975, c. 65 (U.K.), Disability Discrimination Act 1995, c. 50 (U.K.) and Administration of Justice Act 1982, c. 53 (U.K.).

78 BEVERLEY-SMITH, supra note 73, at 124.

79 Indeed, Jones and Wilson in 2007 reported fears that personality rights were "Continental psychobabble." Victoria Jones \& Alastair Wilson, Photographs, Privacy and Public Places, 29 EUR. INTEll. PROP. J. 357, 358 (2007). See also Hazel Carty, ch. 7, in WhITTY AND ZIMMERMAN, supra note 73, at 400 ("Despite all of the above developments, there are still no concrete 'personality rights' in English law.").

80 See BEVERLEY-SMith, supra note 73 passim; BlACK, supra note 73, Part I; BRUGGEMEIER, supra note 73 , at $25-28$.

81 See Raymond Wacks, Why There Will Never Be an English Common Law Privacy Tort, in New Dimensions in Privacy LaW: InTERnational AND COMPARATIVE PERSPECTIVES 15483 (Andrew T. Kenyon \& Megan Richardson eds., 2006).

82 See infra. 
confidence, libel, passing off as "false endorsement" 83 and unfair competition. ${ }^{84}$ Nevertheless, many European authors currently argue that the common law is beginning to take protection of personality rights more seriously in a way more akin to civilian countries, partly due to the obligations imposed by the European Convention on Human Rights ("ECHR"), which are promoting the growth of a harmonised European law of public fundamental rights. ${ }^{85}$ In particular, judicial activism since the incorporation of the ECHR into U.K. law via the Human Rights Act of 1998 has led to the effective development of an English tort of privacy ${ }^{86}$ via the vehicle of the tort of breach of confidence. ${ }^{87}$ Similarly, as the importance and commercial value of image rights has grown, the U.K. courts have made considerable progress in finding remedies for unauthorised use of images via notions of passing off; 88 however, as Black points out, these still contain a gap in not providing a celebrity or other person (i.e., an assignee) with a positive right to exploit rather than merely the negative right to prevent unauthorised persons from exploiting their image. ${ }^{89}$ Judicial developments have not, however, gone so far as to develop a surrogate publicity right which is transmissible on death. Indeed, where attempts were made to find such a remedy via trademark law, the English courts established a clear precedent that the name, image or "personality" of a dead celebrity (such as Princess Diana or Elvis Presley) cannot be protected by trademark, simply because diverse goods and services bearing that likeness or name are sold without authorisation of the estate. $^{90}$

\section{Civilian Systems}

By contrast, many states whose legal system derives partly or wholly from civilian tradition have historically been more inclined to recognise both the principled existence of personality rights, and their persistence after death, for reasons related to the historical respect for notions of liberty, dignity and reputation, especially of creators. In such a tradition, the main driver of respect for personality rights is arguably

\footnotetext{
83 See Irvine v. TalkSport Ltd., [2003] EWCA (Civ) 423, [2003] 1 W.L.R. 1576 (Eng.).

84 See, e.g., Sim v. HJ Heinz, [1959] 1 WLR 313 (Eng.).

85 BRUGGEMEIER, supra note 73, chs. 1-2; WHITTY AND ZIMMERMAN, supra note 73, at 479-99.

86 This cause of action is not referred to as the "tort of privacy," however-it is sometimes known as "misuse of private information." See Campbell v. MGN Ltd., [2004] UKHL 22 [31], [2004] 2 A.C. 457 (appeal taken from Eng.).

87 See Douglas v. Hello!, [2003] EWHC (Ch) 786, [2003] 3 All E.R. 996 (Eng.); Douglas v. Hello!, [2005] EWCA (Civ) 595, [2006] Q.B. 125 (Eng.); Douglas v. Hello!, [2007] UKHL 21, [2006] Q.B. 125 (Eng.); Campbell, [2004] UKHL 22.

88 See Irvine v. Talksport Ltd., [2003] EWCA (Civ) 423.

89 BLACK, supra note 73, at 22.

90 See Elvis Presley Enters. Inc. v. Sid Shaw Elvishly Yours, [1999] EWCA (Civ) 964; Diana, Princess of Wales Trade Mark, [2001] E.T.M.R. 25.
} 
non-economic (though the two are of course inextricably intermixed) so the likelihood of transmission of the right on death is much greater than in common law. Nonetheless, there are significant differences even among the key civilian legal systems as to transmission of personality interests on death. For example, in Germany, the protection of human dignity derives from its highest constitutional source, Article 1 of the Basic Law, ${ }^{91}$ which has been applied to protect the honour of a deceased person. In the Mephisto ${ }^{92}$ and Marlene Dietrich ${ }^{93}$ cases, the German courts granted protection for both the non-commercial interests (dignity, privacy) and commercial interests of the deceased (the use of name, voice, or image for financial gain), ${ }^{94}$ noting:

It would be inconsistent with the constitutional mandate of the inviolability of human dignity, which underlies all basic rights, if a person could be belittled and denigrated after his death. Accordingly an individual's death does not put an end to the state's duty under Art. 1 I GG to protect him from assaults on his human dignity. ${ }^{95}$

However, in a different part of the civilian tradition, the French courts and legislature have taken a different position. For example, French law distinguishes between the economic and personal aspects of personality rights (a dualistic conception, as opposed to the German monistic position $)^{96}$ and treats the latter as non-transmissible. ${ }^{97}$ In $S A$

91 GRUNDGeSETZ FUR DIE BundesRepublik Deutschland [GRUNDGESETZ] [GG] [Basic Law], May 23, 1949, BGB1. I (Ger.).

92 Bundesverfassungsgericht [BVerfGE] [Federal Constitutional Court] Feb. 24, 1971, 30, 173, translated in J. A. Weir, Institute for Transnational Law, Foreign Law Translations, UNIV. OF TEX. AT AUSTIN, SCH. OF LAW, http://www.utexas.edu/law/academics/centers/transnational/ work_new/german/case.php?id=1478 (last visited Sept. 15, 2013).

93 Bundesgerichtshof [BGH] [Federal Court of Justice] Dec. 1, 1999, BGH 1 ZR 49/97, translated in Raymond Youngs, Institute for Transnational Law, Foreign Law Translations, UNIV. OF TEX. AT AUSTIN, SCH. OF LAw, http://www.utexas.edu/law/academics/centers/ transnational/work_new/german/case.php?id=726 (last visited Sept. 15, 2013).

94 The court stated:

The components of the right of personality which are of financial value remain after the death of the holder of the right of personality, at any rate as long as the nonmaterial interests are still protected. The corresponding powers pass to the heir of the holder of the personality right and can be exercised by him in accordance with the Id. express or presumed will of the deceased.

95 Weir, supra note $92, \S 6$.

96 For a good summary of this distinction, see WhitTY AND ZIMMERMAN, supra note 73, ch. 1, ฯ9 $3-4,9$.

97 This distinction originates with Perreau, in his famous article on "Des droits de la personnalité," published in 1909. The article delivered a taxonomy of personality rights in France, distinguishing between rights concerning the physical individual (life, limb and health, including consent to medical treatment) and those concerning the moral personality (honour, liberty and intellectual works - moral rights). The latter had effect erga omnes and could not be evaluated in monetary terms. They were thus inalienable, imprescriptible and non-inheritable. They could only be exercised and enforced by the "owner" herself. See WHITTY AND ZIMMERMAN, supra note 73, at 320 . 
Editions Plon v. Mitterand, the Court of Cassation held that "the right to act in respect of privacy disappears when the person in question, the sole holder of that right, dies." 98 Bruggemheier concludes therefore that "the right to one's image is of a moral and pecuniary nature: the economic right which allows pecuniary gain from commercially exploiting the image is not purely personal and can be passed on to the heirs." 99 He notes that this partial post-mortem transmission of image rights also applies to non-public figures. ${ }^{100}$

\section{U.S. Law}

Although the U.S is also a common law system, legal developments have taken a somewhat different turn than those in England. In the Restatement (Second) of Torts, the American Legal Institute takes a stance similar to English law that a person's privacy interest ends upon his death. ${ }^{101}$ According to the Restatement, there can be no cause of action for invasion of privacy by (or on behalf) of a dead person, with the exception of "appropriation of one's name or likeness." 102 As a result, some personality rights can, indeed, be protected after death either in common law or by statute, and are then known generally under the rubric of "publicity rights." Although the exact content of these rights varies from state to state, since they are not harmonised at the federal level, it is fair to say that the U.S. conception of post-mortem transmission of publicity rights depends on the conception of these rights as property. ${ }^{103}$ The growth of publicity rights has been intimately connected to the growth of a market for the exploitation of celebrity images, a market that is almost entirely concerned with economic rather than privacy interests. The key question is not whether a celebrity's privacy can be protected but rather who has the right to exploit it (or to sue someone for exploiting it without authorisation). Rights are most commonly exercised not by the

98 SA Editions Plon v. Mitterand, Cour de cassation [Cass.] [supreme court for judicial matters] May 27, 1997, JCP 1977, II, 22894 (Fr.) (citing December 14, 1999, Bull. Civ. 1, no. 345 (Fr.)), translated in Tony Weir, Institute for Transnational Law, Foreign Law Translations, UNIV. OF TEX. AT AUSTIN, SCH. OF LAW, http://www.utexas.edu/law/academics/centers/transnational/ work_new/french/case.php?id=1240 (last visited Sept. 15, 2013).

99 Id.

100 BRUGGEMEIER, supra note 73, at 17.

101 See RESTATEMENT (SECOND) OF TORTS § 652I (1977) ("Except for the appropriation of one's name or likeness, an action for invasion of privacy can be maintained only by a living individual whose privacy is invaded.").

102 Id.

103 See Zacchini v. Scripps-Howard Broad. Co., 433 U.S. 562 (1977) (distinguishing the tort of invasion of privacy from infringement of a right of publicity by emphasising that the interest protected through a cause of action for a false light invasion of privacy was an interest in reputation, whereas the right of publicity protected the proprietary interest of the individual.). See Harry Kalven Jr., Privacy in Tort Law: Were Warren and Brandeis Wrong?, 31 LAW \& CONTEMP. PROBS. 326 (1966). 
person whose image is in question but by assignees whose business it is to commercially exploit images and who make very large amounts of money doing so. ${ }^{104}$ Some states have no version of a publicity right per se, but the right is statutory in nineteen states, and a further twenty-eight recognize the right via common law. ${ }^{105}$

The first significant right of publicity case was the decision of the Second Circuit Court of Appeals in Haelan Laboratories Inc v. Topps Chewing Gum Inc., where the issue was whether a chewing gum company could prevent the unauthorised use of the image of famous baseball players who had contractually endorsed that product, by a rival chewing gum company. ${ }^{106}$ The court did not explore, in much detail, the question of whether this right was of a proprietary nature, but rather took a common sense view that a man should have a right in the publicity value of his own photograph, stating: "whether it be labeled a 'property' right is immaterial; for here, as often elsewhere, the tag 'property' simply symbolises the fact that courts enforce a claim which has a pecuniary worth."107

Westfall and Landau have suggested that this initial vague theoretical and instrumentalist background meant there were no obvious parameters to guide the judicial or legislative development of the right of personality after Haelan, resulting in these rights being extended to ever-wider aspects of identity. ${ }^{108}$ It is unsurprising then that we find a patchwork development of post-mortem publicity rights too, across the various U.S. states. At common law, survival of the right of publicity on death has been recognised in Georgia, New Jersey, and in Tennessee; and by statute, in California, Indiana and other states. Hicks determined that, in total, sixteen states recognise a post-mortem right of publicity under statute or common law, while two states explicitly refuse to recognise a post-mortem right of publicity. ${ }^{109}$

\footnotetext{
104 For example, CMG Worldwide ("CMG") is an Indiana company, and licensing agent, that reaps between $\$ 12$ and $\$ 20$ million in annual revenue by representing Monroe, Babe Ruth, James Dean, and more than 250 other deceased celebrities. See Michael Decker, Goodbye, Norma Jean: Marilyn Monroe and the Right of Publicity's Transformation at Death, 27 CARDOZO ARTS \& ENT. L.J. 243, 245-46 (2009). In 2007, CMG earned more than \$7 million from ventures using Monroe's identity. Id. at 246. CMG's Chief Executive Officer, Mark Roesler, claims to have been the "driving force" behind Indiana's right of publicity statute, which he calls "the most progressive and celebrity-friendly worldwide." As Decker states, "[a]ccording to The New York Times, Roesler's fees begin at one-third of the profits; by comparison, a standard agent's fee is ten percent." Id.

105 See Statutes, Right of publicity, http://rightofpublicity.com/statutes (last visited Sept. 17, 2013).

106 Halean Laboratories, Inc. v. Topps Chewing Gum, Inc., 202 F.2d 866 (2d Cir. 1953).

107 Id. at 868 (Frank, J.); see also BLACK, supra note 73, at 13; Melville B. Nimmer, The Right of Publicity, 19 LAW \& CONTEMP. PROBS. 203 (1954).

108 David Westfall \& David Landau, Publicity Rights as Property Rights, 23 CARDOZO ARTS \& ENT. L.J. 71 (2005).

109 Aubrie Hicks, The Right to Publicity after Death: Post-Mortem Personality Rights in Washington in the Wake of Experience Hendrix v. HendrixLicensing.com, 36 SEATTLE U. L. REV.
} 
The duration of the right of publicity after death also varies from state to state. For example, Florida recognises the right for forty years after death, Illinois for fifty years, California for seventy years and Indiana for one hundred years. ${ }^{110}$ Of those that have, a right of postmortem duration of between ten and one hundred years seems typical. ${ }^{111}$ However, many jurisdictions have not yet considered the post-mortem issue. Given the overwhelmingly economic purposes underpinning the creation of publicity rights, most publicity rights originally benefited only celebrities, for whom image represented a serious revenue stream. ${ }^{112}$ However, several states, including Nevada, Illinois and Washington, have also extended post-mortem publicity rights to noncelebrities. ${ }^{113}$ However, in those jurisdictions, lack of celebrity status generally has an impact on the post-mortem duration of publicity rights: for example, in Washington, personality rights for deceased noncelebrities are only protected for a term of ten years after death, whereas celebrity reputations are protected for seventy-five years after death. ${ }^{114}$

\section{B. Defamation}

Defamation may plausibly be seen as just one of the subset of rights we gathered together under the rubric of personality rights. It has, however, some interesting features in relation to post-mortem privacy that make it worthy of attention. Defamation canonically can be distinguished from privacy torts in that it operates only where false statements or impressions have been published about a person's reputation. As such, it operates in the hinterland between a pure persona right (reputation, dignity or honour) and a property right (akin to goodwill or brand). As noted above, common law jurisdictions have traditionally stated, as a matter of principle, that purely personal obligations "die with the person." 115 Although this principle has been attenuated in many common law jurisdictions, it still holds fast in

$275,276(2012)$

110 John E. Ottaviani \& Allison A. Reuter, Maybe You Can Take it With You: Post-Mortem Rights of Publicity in the United States, WORLD TRADEMARK REV., 118-19 (Oct./Nov. 2012).

111 Id. at 118.

112 See Mark Bartholomew, A Right Is Born: Celebrity, Property, and Postmodern Lawmaking, 44 CONN. L. REV. 301, 355 (2011) (noting that "[i]t was only in the last years of the twentieth century that judges repeatedly took pains to note the universal eligibility for the right of publicity.").

113 See Nev. Rev. Stat. AnN. § 597.790 (West 2011); 765 Ill. Comp. Stat. AnN. 1075/10 (West 1999); see infra note 114. Indeed, a literature is emerging that argues that if publicity rights are to exist they should apply equally to all, celebrities and non-celebrities, with a differentiation being made in the amount of damages payable for unauthorised appropriation of image, personality, etc. For an overview, see Mark Bartholomew, supra note 112.

114 WASH. REV. CODE ANN. $\S \S 63.60 .020,63.60 .040$ (West 2013).

115 See supra note 77. For a comparison between the U.S. and German perspectives, see Hannes Rösler, Dignitarian Posthumous Personality Rights-An Analysis of U.S. and German Constitutional and Tort Law, 26 BERKELEY J. OF INT'L L. 153, 153-05 (2008). 
English law in relation to defamation. This has been confirmed very recently in the case of Harvey Smith v. Bobby Dha, where the court held that no ruling could be given in a defamation action where the claimant died while waiting for judgment to be handed down. ${ }^{116}$ Mrs. Justice Nicola Davies maintained:

No one other than a claimant can give reliable evidence about his or her feelings or distress. No one other than a defendant-should a defendant die - can give reliable evidence to rebut a plea of malice. It cannot be right that some libel actions abate and others do not, depending on the arguments raised in them or the stage of proceedings. ${ }^{117}$

It is interesting that although there is a brief reference to "the unsatisfactory nature of this principle,"118 this judgment seems mainly based on practical issues of procedure and evidence in any future appeal, rather than theoretical justifications that a right in libel as a persona interest should die with the claimant.

In the United States, the Restatement (Second) of Torts also appears to be clear on the matter stating that: "One who publishes defamatory matter concerning a deceased person is not liable either to the estate of the person or to his descendants or relatives." 119 This is also supported by case law. ${ }^{120}$ However, many U.S. states have begun slowly to reject the concept that libel claims die with the victim. ${ }^{121}$ Some support has been garnered here from the U.S. Supreme Court decision in Swidler \& Berlin v. United States, which recognized that a person's interest in protecting his reputation does not end upon his death. ${ }^{122}$ Currently, however, Rhode Island is still the only U.S. state that provides a cause of action for defamation of the dead, and even then only in very limited circumstances, ${ }^{123}$ although some other states allow

116 See Harvey Smith v. Bobby Dha, [2013] EWHC 838 (QB) (Eng.).

117 Id. $\mid 13$.

$118 I d$.

119 Restatement (SECOND) OF TORTS, § 560 (1977).

120 See generally Raymond Iryami, Give the Dead Their Day in Court: Implying a Private Cause of Action for Defamation of the Dead from Criminal Libel Statutes, 9 FORDHAM INTELL. PROP. MEDIA \& ENT. L.J. 1083, 1088 n.33 (1999).

121 See generally Florence Frances Cameron, Defamation Survivability and the Demise of the Antiquated "Acto Personalis" Doctrine, 85 COLUM. L. REV. 1833 (1985).

122 See Swidler \& Berlin v. United States, 524 U.S. 399 (1998). Chief Justice William Rehnquist, writing for the majority, stated that it is unreasonable to assume that a person's interest in his reputation ends upon his death. Id. Justice Sandra D. O'Connor agreed in her dissenting judgment. See id. at 2086-89. See also Elizabeth Dillinger, Mutilating Picasso: The Case for Amending the Visual Artists Rights Act to Provide Protection of Moral Rights After Death, 75 UMKC L. REV. 897 (2007).

123 The defamation must be published as a part of an obituary or a similar notice within three months of death. The statute also imposes a one-year of limitation for the possible plaintiffs. R.I. GEN. LAWS § 10-7.1-1 (1974) 
the suits to survive where a plaintiff dies while the suit is pending. ${ }^{124}$

Interestingly, in both common law and civilian tradition, defamation is often still subject to criminal prosecution as well as civil action. Orsi notes as a peculiarity of U.S. state laws, given the general extinction of civil liability for defamation post-mortem, that there are five states-Colorado, Idaho, Georgia, Louisiana, and Nevada - that retain criminal statutes regarding defamation of the dead. ${ }^{125}$ One of the most prominent reasons for allowing such post-mortem defamation prosecutions does not appear to be related to economic motivations. Rather, the deceased's family and heirs would want to preserve the truth of their relative's reputation, to keep the record straight. ${ }^{126}$ Brown, opposing such laws, however, notes that the boundaries of such a cause of action are difficult to ascertain, and that allowing a cause of action for defamation of the dead would hamper historical research. ${ }^{127}$

In civilian systems, as might be expected following their more dignitary tradition, the law provides for actions to protect the memory of the deceased, and the honour of his heirs, spouse or legatees. ${ }^{128}$ In Germany, Criminal Code, Section 189,129 prohibits violating the memory of the dead. Further, under $\S 823$ (I) of the German Civil Code, defamation could be perceived as unlawful interference with "other rights" or protected under general personality rights. ${ }^{130}$ Therefore, given Germany's monistic conception of personality rights under which both persona and economic aspects of personality rights survive death, as seen above, rights to sue in defamation can survive the death of the claimant.

\section{Moral Rights}

Moral rights are interesting to look at in the context of postmortem privacy as the dignitary or reputational side of the economic institution of copyright. In some ways, these rights straddle the gap between personality interests based on tort, as in the European personality rights discourse discussed above, and those based on

124 Lisa Brown, Dead But Not Forgotten: Proposals for Imposing Liability for Defamation of the Dead, 67 TEX. L. REV. 1525, 1531(1989).

125 Orsi, Defamation: Tort or Crime? A Comparison of Common Law and Civil Jurisdictions, 9 DARTMOUTH L.J. 19, 26 (2011); Iryami, supra note 120, at 1180.

126 Brown, supra note 124, at 1556.

127 Id.

128 See, e.g., Loi du 29 juillet 1881 sur la liberté de la presse [Law of July 29, 1881 on the Freedom of the Press], Journal OfFICIEL DE LA RÉPUblique Frances [J.O.] [OFFICIAL GAZETTE OF FRANCE], July 30, 1881, art. 34, p. 4201.

129 Strafgesetzbuch [StGB] [PenAl CODE], Nov. 13, 1998, Bundesgesetzblatt, Teil I [BGBL I] 3322.

130 See Maryann McMahon, Defamation Claims in Europe: A Survey of the Legal Armory, 19 WTR COMM. LAW. 24 (2002). 
property, as in the constructed regime of U.S. publicity rights. ${ }^{131}$ Famously, moral rights of authors originate from the French legal tradition and the concept of droit d'auteur. ${ }^{132}$ Although the scope and extent of moral rights vary considerably within the different civilian traditions, the strongest opposition to moral rights has come from the United States system, which finds the civilian idea of an inalienable, perpetual, non-attachable dignitary right — which needs to be considered alongside the economic interests in copyright if creative works are to be efficiently exploited-somewhat alien. However, due to the signing of the Berne Convention for the Protection of Literary and Artistic Works, limited protection for moral rights has been established in the United States. ${ }^{133}$ The original version of the Berne Convention did not provide any protection to artists' moral rights. In revisions adopted in Rome in 1928, an article on moral rights was added to the Berne Convention. ${ }^{134}$ In subsequent rounds of negotiations, the extent of moral rights protection each signatory state must provide as a minimum has been reduced based upon pressure from the United States. The World Intellectual Property Organization ("WIPO") now interprets Berne as implying "that a complete extinction of the moral rights on the death of the author is not permitted, [but] Union countries [can] permit one or other of the rights comprising the moral right to lapse after this date."135

131 Beverley-Smith notes that "while the categorisation of the moral right as a specific personality right may be disputed, the exploitation of a work which interferes with the author's moral right raises similar questions as the exploitation of other aspects of personality." See BEVERLEY-SMITH supra note 73 , at 112 . Interestingly, Black, in her model scheme for a Scots law of personality rights, chooses to categorise them not as privacy or property rights but as akin to an IP right in being limited monopolies. BLACK, supra note 73, at 147-49.

132 See Robert C. Bird \& Lucille M. Ponte, Protecting Moral Rights in the United States and the United Kingdom: Challenges and Opportunities Under the U.K.'S New Performances Regulations, 24 B.U. INT'L L.J. 213 (2006); Cheryl Swack, Safeguarding Artistic Creation and the Cultural Heritage: A Comparison of Droit Moral Between France and the United States, 22 COluM.-VLA J.L. \& ARTS 361 (1998); Michael W. Carroll, Whose Ownership Is It Anyway?: How We Came to View Musical Expression as a Form of Property, 72 U. CIN. L. REV. 1405 (2004).

133 See Berne Convention for the Protection of Literary and Artistic Works, Sept. 9, 1886, revised at Paris July 24, 1971, 25 U.S.T. 1341 (entered into force for the United States March 1, 1989).

134 The new provision declared:

Independently of the author's economic rights, and even after the transfer of the said rights, the author shall have the right to claim authorship of the work and to object to any distortion, mutilation or other modification of, or other derogatory action in relation to, the said work, which would be prejudicial to his honor or reputation.

World INTEllectual Prop. ORG., GUide to the Berne CONVENTION FOR THE PROTECTION OF LITERARY AND ARTISTIC WORKS (PARIS ACT, 1971) 41 (1978) [hereinafter GUIDE TO THE BERNE CONVENTION], available at ftp://ftp.wipo.int/pub/library/ebooks/historical-ipbooks/ GuideToTheBerneConventionForTheProtectionOfLiteraryAndArtisticWorksParisAct1971.pdf (quoting Berne Convention, supra note 126, art. 6bis, \1).

135 See generally GUIDE TO THE BERNE CONVENTION; see also Dillinger, supra note 122, at 903 (noting that interestingly, this "was apparently a concession to the fact that protection of moral rights in common-law countries would be provided in part through the law of defamation, and that no common-law cause of action exists for defamation of a dead person."). 
Accordingly, in the United States federal implementation of moral rights in 1990 recognised only the rights of attribution and integrity for creators of visual works, lasting for the lifetime of the creator. ${ }^{136}$ However, the Act makes it clear that state laws providing protection to moral rights after an artist's death remain in effect and are not preempted by the new federal law. ${ }^{137}$

By contrast, civilian systems, again in line with their dignitary tradition, tend to award clear, extensive and long-lived moral rights to creators of all kinds of literary and artistic works. The moral right is perceived "as a natural and personal right rather than as a purely legal right," deriving "from the French belief that artists pour a part of their soul into their work, creating a personal link between themselves and their creations." 138 Thus in France, creators' moral rights are perpetual, as a consequence of the dualistic conception of copyright mentioned earlier (i.e., a separate treatment of economic and moral rights); in Germany, moral rights last as long as economic rights, as a consequence of their monistic conception. ${ }^{139}$ In the United Kingdom, moral rights (including the right to privacy of certain photographs and films) also subsist as long as copyright in a work subsists, except for the right against false attribution of work, which only lasts until twenty years after a person's death. ${ }^{140}$ However, as in the United States, moral rights in the United Kingdom have been watered down, and though they still cannot technically be assigned, they can be waived ${ }^{141}$ and frequently are (e.g. in publishing contracts). Moral rights thus represent a significant route through which post-mortem preservation of personality interests in privacy, honour and reputation can be guaranteed well after the death of a creator in civilian systems, but are likely to be limited in scope or signed away in common law systems where publication of a creative work is undertaken by an intermediary.

136 See Visual Artists Rights Act 1990, Pub. L. No. 101-650, 104 Stat. 5130 (codified at 17 U.S.C. § 106A (2012)).

137 See Jill R. Applebaum, Comment, The Visual Artists Rights Act of 1990: An Analysis Based on the French Droit Moral, 8 Am. U. J. Int'1 L. \& Pol'y 183, 210 \& n.197 (1992). For more on the state moral rights laws in existence at that time, see Edward J. Damich, State "Moral Rights" Statutes: An Analysis and Critique, 13 COLUM.-VLA J.L. \& ARTS 291, 323 (1989).

138 Dillinger, supra note 122.

139 For a useful comparison between English, French and German law attitudes to moral rights, see S. Newman, The Development of Copyright and Moral Rights in the European Legal Systems, 33 Eur. Intell. Prop. Rev. 677, 677-89 (2011).

140 See Copyright, Designs and Patents Act 1988, c. 48, §§ 77-86 (Eng.) [hereinafter CDPA]; see also L. Bently \& B. Sherman, Intellectual Property Law 167 (3d ed. 2008); Hector MacQueen et al., Contemporary Intellectual Property: Law and Policy, 104-118 (2d ed. 2011).

141 See CDPA § 87; see also Neil Netanel, Alienability Restrictions and the Enhancement of Author Autonomy in United States and Continental Copyright Law, 12 CARDOZO ARTS \& ENT. L.J. 1, 49 (1994); David Vaver, Moral Rights Yesterday, Today and Tomorrow, 7 INT'L J.L. INFO. TECH. 270, 270-78 (1999). 


\section{Data Protection}

EU data protection ("DP") law is arguably the most important legal instrument for protection of informational privacy in Europeboth offline and online, and against both state and private actors-and has been a model for informational privacy throughout many other parts of the world. ${ }^{142}$ It is currently going through a substantial and controversial process of reform to meet the challenges of the digital era, which is hoped to culminate in a new Data Protection Regulation ("DPReg") in 2014. ${ }^{143}$ It is, unlike in the United States, an "omnibus," rather than sectoral, privacy protection regime. The complex rules are found in the EC Data Protection Directive ("DPD"), ${ }^{144}$ and in its later extension the EC Privacy and Electronic Communications Directive ("PECD"). ${ }^{145}$ The DPD is required to be implemented in substance into the national laws of each EU state, though local legislatures have substantial autonomy in how they do this. EU DP law is currently explicitly founded on the right to respect for the private life of individuals protected by Article 8 of the European Convention on Human Rights (“ECHR”) ${ }^{146}$.

DP law aspires to give "data subjects" control over the "processing" of their "personal data."147 The DPD defines personal data as, "any information relating to an identified or identifiable natural person ('data subject')" where an identifiable person is "one who can be identified, directly or indirectly, in particular by reference to an identification number or to one or more factors specific to his physical,

142 See, e.g., Global Privacy Protection: the First Generation (James B. Rule \& G.W. Greenleaf eds., 2008).

143 Proposal for a Regulation of the European Parliament and of the Council on the Protection of Individuals with Regard to the Processing of Personal Data and on the Free Movement of Such Data (General Data Protection Regulation), COM (2012) 11 final (25.1.2012) [hereinafter Data Protection Regulation (DPReg)].

144 Council Directive 95/46/EC of the European Parliament and of the Council of 24 October 1995 on the Protection of Individuals with Regard to the Processing of Personal Data and on the Free Movement of Such Data 23/11/1995, 1995 O.J. (L 281) 31-50 [hereinafter Data Protection Directive (DPD)]. For a longer introduction to the DP regime, see Edwards, supra note 9, chs. 14-16.

145 Council Directive 2009/136/EC of the European Parliament and of the Council of 25 November 2009 and Amending Council Directive amending Directive 2002/22/EC on Universal Service and Users' Rights Relating to Electronic Communications Networks and Services, Directive 2002/58/EC Concerning the Processing of Personal Data and the Protection of Privacy in the Electronic Communications Sector and Regulation (EC) No 2006/2004 on Cooperation Between National Authorities Responsible for the Enforcement of Consumer Protection Laws [hereinafter Privacy and Electronic Communications Directive (PECD)]. These changes were to be implemented in the E.U. by May 25, 2011, however, many states have been late to meet this deadline.

146 See supra note 144, , 10.

147 In addition, the law provides a large number of associated post-collection rights such as the right to access one's personal data and correct it for errors; the right to have it kept securely; the right not to have it used for cold calling without consent. See supra note 144, Art. 2(a). 
physiological, mental, economic, cultural or social identity." 148 This definition of personal data is contested in scope both across different EU states, and in the current reform process, but it certainly extends to cover many of the digital assets discussed in this Article, such as emails and social media profiles. Processing is defined very widely to include "any operation or set of operations performed upon personal data," including, but not restricted to: collection, recording, organisation, storage, alteration, retrieval, use, disclosure or deletion of personal data. 149

Thus, it can be seen that DP law is an important viable route by which European Web users might attempt to control the collection and use of their personal data associated with the creation, storing and sharing of digital assets. As seen above in Part III however, on intermediary platforms such as Facebook, Twitter, YouTube, etc., the fair and lawful processing requirement DP imposes, and specifically grounds for processing, is usually regarded as met by the consent granted by a user when registering to use the platform. Such consent, given as part of a standard term, non-negotiable consumer contract, is most likely often not sufficient to meet the DPD's requirements of that consent being a "freely given specific and informed indication of [the user's] wishes," 150 but presently no formal challenge in the European Court of Justice has ascertained this. ${ }^{151}$

The DPD, understandably given its fundamental connection with Article 8 of the ECHR which itself applies, like other human rights, only to the living, ${ }^{152}$ only protects personal data of "natural persons," usually interpreted to mean the living. However, given the discretion in implementation any directive affords to EU member states to offer more than the minimum protection required to its own nationals, ${ }^{153}$ some EU states have nonetheless used DP law to offer some kind of post-mortem data protection, even if limited in its scope, and for a restricted period of time after death. Only a few member states have, however, taken advantage of this possibility. Bulgaria recognises that in event of death

148 DPD, art. 2(a)

149 DPD, art. 2(b)

$150 \mathrm{DPD}$, art. 2(h)

151 See generally Edwards, supra note 24; Opinion of the Working Party on the Protection of Individuals with Regard to the Processing of Personal Data, Article 29 WP, Opinion 15/2011 on the Definition of Consent, 01197/11/EN, WP 187 (July 13, 2011).

152 Jäggi v. Switzerland, App. No. 58757/00, 47 Eur. H.R. Rep. 30 (2006); Estate of Kresten Filtenborg Mortensen v. Denmark, App. No. 1338/03, 2006-V Eur. Ct. H.R. (2006); Koch v. Germany, App. No. 497/09, Eur. Ct. H.R. (2012).

153 See Case C-101/01, Criminal Proceedings Against Lindqvist, 2003 E.C.R. I-12971, I-13027 (European Court of Justice decision deferring to the national court's resolution of the issue) ("On the other hand, nothing prevents a Member State from extending the scope of the national legislation implementing the provisions of Directive 95/46 to areas not included within the scope thereof, provided that no other provision of Community law precludes it."). 
of the natural person "his or her rights ... shall be exercised by his or her heirs," 154 thus extending the subject's rights of access to personal data, for example, to the heirs of the data subject. The Estonia Personal Data Protection Act goes even further, giving a considerable amount of freedom to data subjects to decide in advance of death what uses of their personal data they will consent to. ${ }^{155}$ In Section 12 it states: "[t]he consent of a data subject shall be valid during the life of the data subject and thirty years after the death of the data subject, unless the data subject has decided otherwise." 156 Furthermore, in Section 13(1), it entitles certain family members to permit processing of personal data after the death of the data subject, but again for no more than thirty years after death. ${ }^{157}$

Conversely, the Swedish Personal Data Protection Act explicitly restricts personal data rights to the living, defining personal data as "all kinds of information that directly or indirectly may be referable to a natural person who is alive." 158 Similarly, the UK Data Protection Act 1998 defines personal data as "data which relate to a living individual." 159 This is by far the majority approach, with the term "natural person" generally transposed without alteration. The Article 29 Working Party, which comments authoritatively, though not bindingly, on interpretation of the DP regime, has stated that: "[i]nformation relating to dead individuals is ... in principle, not to be considered as personal data, subject to the rules of the Directive." 160 However, the WP also noted that, in certain cases, the deceased's data could receive some kind of protection from DP law where protection could be awarded indirectly (since the data of the deceased could be connected to those of a living person), and that it is in the discretion of member states to extend the scope of national legislation, as already noted. ${ }^{161}$

In general, though, the reluctance of states to extend DP rights to the dead matches the perceptions, canvassed above, that such rights, as highly personal to the data subject, should by their nature, die with them. Where interests such as family reputation, morals or economic inheritance of the living are affected after the death of the data subject, other institutions such as criminal defamation laws, moral rights,

154 Personal Data Protection Act, Jan. 1, 2002, State Gazette [SG] No. 1/4.01.2002, at Art. 28(3), as amended (Bulg.), available at http://legislationline.org/topics/country/39/topic/3.

155 Personal Data Protection Act, Oct. 1, 2003, Riigi Teataja [RT] I 2003, 26, 158, amended by RT I 2004, 30, 208 (Est.), available at $\mathrm{http} / /$ www.legaltext.ee/text/en/X70030.htm.

156 Id. $\S 12$.

157 Id. $\S 13$.

158 Personal Data Protection Act (SFS 1998:204) § 3 (Swed.), available at http://www. sweden.gov.se/content/1/c6/01/55/42/b451922d.pdf.

159 Data Protection Act 1998, c. 29, Part I § (1)(e) (U.K.).

160 Article 29 Data Protection Working Party, Opinion 4/2007 on the Concept of Personal Data, 01248/07/EN, WP 136, at 22.

$161 \mathrm{Id}$. at $16,22-23$. 
copyright or personality rights may instead provide a remedy. Where personal data is shared with the relatives of a deceased (e.g., genetic data) they will have their own rights to exercise as living persons. Accordingly, it seems that even within the current protracted reform of the DPD, there has been little support for the extension of DP to protect post-mortem informational privacy, and some explicit opposition. The European Commission Proposal for the General Data Protection Regulation does not mention deceased persons or their data at all. ${ }^{162}$ However, the current draft definitions of personal data and the data subject, in Article 4 of the Proposal, cover only natural persons' data, as in the current DPD. ${ }^{163}$ Moreover, in the revised version proposed by the Council of the European Union in June 2012, deceased persons were explicitly excluded as data subjects, which stated: "[t]he principles of data protection should not apply to deceased persons."164 The most recent European Parliament Draft Report, however, does not contain this amendment, so the final result remains open; however, expansion of the rights of the deceased under DP law certainly seems highly unlikely. ${ }^{165}$

One key issue here, as with personality (and publicity) rights, would be the practicalities of such post-mortem DP rights. Who would exercise them on behalf of the deceased data subject, and for how long? Should they exercise them as trustees, with reference only to the supposed wishes, expressed or implied, of the deceased, or according to their own wishes or the desires of the surviving family? What would the consequences be for the autonomy and freedom of expression of the living, and the public and historical record? We return to these implementation points below.

\section{E. Freedom of Testation}

Finally, some authors argue that freedom of testation is another aspect of the testator's personality rights. As such, Sonnekus argues that freedom of testation cannot be detached from an individual, nor delegated to or transferred from another person. ${ }^{166}$ Similarly, other

\footnotetext{
162 See generally Proposal for Regulation, supra note 143.

163 Id. art. 4.

164 Revised Recital 23, Council of the European Union, Letter from the Presidency to Working Party on Data Protection and Exchange of Information, 2012/0011 (COD), Brussels, June 22, 2012, available at http://amberhawk.typepad.com/files/blog_june2012_eu-council-revised-dpposition.pdf. This amendment was advocated by the Council representative of Sweden, a country that already explicitly excludes the deceased's data, see supra note 158 .

165 See Amendments 14 and 84 in Draft report on the Proposal for a Regulation of the European Parliament and of the Council on the Protection of Individual with Regard to the Processing of Personal Data and on the Free Movement of Such Data (General Data Protection Regulation), Comm. on Civil Liberties, Justice and Home Affairs, 2012/0011(COD), Dec. 17, 2012 (Rapporteur: Jan Philipp Albrecht).

166 Jean C. Sonnekus, Freedom of Testation and the Aging Testator, in EXPLORING THE LAW OF
} 
writers characterise freedom of testation as the manifestation of private autonomy, having a considerable effect on the emancipation of the individual. ${ }^{167}$ It may seem somewhat odd, therefore, that countries that provide more protection for personality rights (i.e., civilian countries) in general restrict freedom of testation more than countries that, arguably, provide less protection for personality rights (i.e., common law regimes). For example, in Scotland, a mixed jurisdiction, but one with strong civilian roots to its property law, whether a person dies testate or intestate, the surviving spouse and children have rights known as prior rights (statutory) and legal rights (common law) over the moveable estate. ${ }^{168}$ In England, by contrast, even after a series of legal reforms, freedom of testation reigns, and dependents that are not heirs under the will only have discretionary rights to a share of the estate based on need, not entitlement. ${ }^{169}$

Freedom of testation is thus usually assumed to be much more limited in civilian systems than in common law countries. The theoretical basis of unlimited freedom of testation in common law stems, it is thought, from liberal, laissez-faire economic and social thought. ${ }^{170}$ In civilian countries, by contrast, there is an emphasis on kinship, society and the rights of blood, with the result that certain family members (typically blood children and family, but also sometimes now including a spouse or partner) are given indefeasible claims to a part of the testator's estate regardless of testate disposition. These principles come from ethical, philosophical and natural law thought, which argue for "solidarity between generations," 171 as opposed to the economic and market rationale of common law.

SucCession: Studies National, Historical AND Comparative 78, 79 (Kenneth Reid, Marius J de Waal \& Reinhard Zimmermann eds., Edinburgh University Press 2007) (citing J Goebel).

167 See M. J. de Waal, The Social and Economic Foundations of the Law of Succession, 8 StELLENBOSCH L. REV. 162, 169 (1997); Lawrence M. Friedman, The Law of the Living, the Law of the Dead: Property, Succession and Society, 1966 WIS. L. REV. 340, 355 (1966) (asserting "The power of disposition is felt psychologically to constitute an essential element of power over property.").

168 Michael C. Meston, The Succession (Scotland) ACt (5th ed. 2002).

169 See Inheritance (Provision for Family and Dependants) Act 1975, c. 63 (Eng.).

170 See, e.g., François du Toit, The Limits Imposed Upon Freedom of Testation by the Boni Mores: Lessons from Common Law and Civil Law (Continental) Legal Systems, 11 Stellenbosch L. Rev. 358, 360 (2000); Marius J. de Waal, A Comparative Overview, in EXPLORING THE LAW OF SUCCESSION: STUDIES NATIONAL, HisTORICAL AND COMPARATIVE, supra note 166 , at $1,14$.

171 De Waal, supra note 170, at 15. 


\section{Situating Post-Mortem Privacy in the Digital Assets World: ANALYSIS}

\section{A. Arguments for Post-Mortem Privacy}

Should the privacy of the deceased have legal protection of some kind? We started this Article in Part I with three hypothetical scenarios, grounded in real or typical facts, which would inspire most nonlawyers, we suspect, to think that it should, or might. More generally, and less intuitively, we might argue that the digital and Web 2.0 world has created a new set of circumstances where rights of post-mortem privacy, previously little regarded in law, are now of increasing importance to everyday folk. Some might argue that there have always been disputes over post-mortem publication of unpublished novels and letters against the wishes of the deceased and so nothing very new is going on here. ${ }^{172}$ Darrow and Ferrera, for example, note that private letters, diaries, and photographs can already be inherited and may contain information concerning the deceased that is as private as any found in e-mails. ${ }^{173} \mathrm{We}$ would, however, argue that a number of factors demand the reconsideration of post-mortem privacy in a digital world, including the volume of digital assets preserved after death; the accessibility, durability, shareability, and co-construction (shared ownership) of those assets; and the lack of authorial control over those assets (which are instead subjected to intermediary control).

More than ever before, "ordinary people," leave digital relics which may be highly personal and intimate, and are increasingly preserved and accessible in large volume after death. As a global average, respondents to a 2011 McAfee survey had 2,777 digital files stored on at least one digital device, with a total value of $\$ 37,438.174$ Once, only public figures would have left letters or other personal writings of concern, or accessible, to anyone other than their most immediate friends and family; now everyone on Facebook leaves potentially intimate records of their life (and details of the lives of others, who may survive them) exposed to the entire world after death. Similarly, in the past, letters containing compromising matter could

172 See McCallig, supra note 1; The Inside Story of Nabokov's Last Work, supra note 3.

173 See Edwards \& Harbinja, supra note 9. See also RESTATEMENT (SECOND) OF TORTS § 652I (1977); Humphreys v. DeRoss, 790 A.2d 281, 289 (Pa. 2002) (Castille, J., dissenting) ("Personal belongings, letters, mementos, family photographs and the like are all common bequests ...."). 174 See McAfee Reveals Average Internet User Has More Than \$37,000 in Underprotected 'Digital Assets', MCAFEE (Sept. 27, 2011), http:/www.mcafee.com/hk/about/news/2011/q3/ 20110927-01.aspx. Assets included: entertainment files (e.g., music downloads), personal memories (e.g., photographs), personal communications (e.g., e-mails or notes), personal records (e.g., health, financial, insurance), career information (e.g., resumes, portfolios, cover letters, email contacts) and hobbies and creative projects. Regionally, North American respondents (U.S. and Canada) had the highest perceived value of their total digital assets, with an average cited value of $\$ 52,154$ ( $\$ 54,722$ in the U.S. alone). Id. 
have been easily destroyed or left with strict instructions to destroy to the estate administrator or literary executor, with a reasonable expectation of being kept safe from the public gaze. Now, as seen in the Ellsworth case, such outcomes are uncertain and left to the discretion of webmail company policies and the persistence of the deceased's heirs. Once, many people would have left few, if any, lasting traces of their private lives - a few photos, a few letters perhaps and the fading memories of their children. Now, the traces of the deceased's online lives are left behind and are intensely durable.

As is often said, "Once it was hard to remember; now it is hard to forget." 175 Digital communications are not easily kept private in one place, nor are they easy to destroy or delete from every machine or server where they may have been written, stored or sent. Instead, as intangible digital assets, they can be copied, mirrored and spread around the globe in minutes. In such form, and via such universal and speedy distribution channels, it is more than likely that the author of an electronic communication or text, or owner of an identity, name or reputation will lose control of what happens to it after their death. It may even go "viral," in an orgy of sharing across the Internet.

Another key problem is that the ownership and control of digital assets, including the right to destroy, share or bequeath, remain conflicted and unclear. While this Article has concentrated on privacy, it has been obvious that the question is inextricably merged with that of ownership or property (indeed the use of the term "digital asset" throughout has foreshadowed this), and that the notion of "ownership" in the context of a discussion of privacy means more than reciting the rules of copyright or property law. Is a Facebook profile owned by the subject of the profile, by Facebook or both? Does that determination rest on the platform contract or the law of succession? What if person A comments on person B's profile? Does A "own" the comment and thus have a right to stop B's family from deleting it after B's death? What if B's friends build an entire memorial shrine around person B's profile, as in Scenario 0? Who "owns" the profile then? As we have noted repeatedly, factual control (as opposed to legal ownership) invariably lies with the intermediary where digital assets are stored.

On the subject of ownership, Kasket (a non-lawyer) argues:

The co-constructed nature of a Facebook profile begs the question of whether it represents one person, or a collection of relationships; whether it is created by one individual, or by many; and whether the digital representation of self that is conveyed by it should be viewed

175 See, e.g., VIKTOR MAYER-SCHÖNBERGER, DELETE (2009); DPReg, infra note 179 (regarding the debate over the "right to forget"). 
in the same way as other constituents of that person's physical estate or intellectual property. ${ }^{176}$

She moves on to claim that thus friends (usually ignored in intestate succession) as well as family may have a right to a say in the future of a memorialised profile; and that the issue at hand is not just the privacy of the deceased, or the family, but the "relationship privacy" of all those who had digital relationships with the deceased.

Looking at justifications for post-mortem privacy rights from policy, legal history and culture, key notions seem to be that the living are entitled to shape their image and protect their dignity (and that of their family) after death; that, following the principle of freedom of testation, the wishes of the deceased should be respected; and that protecting the privacy of the deceased also protects the mourning family. But does the law support these notions? The survey of personality laws in Part V gives rise to some general observations.

\section{B. Legal Analysis of Part $V$}

From an Anglo-American common law perspective, the main thread of legal doctrine around post-mortem privacy, albeit one that is somewhat frayed around the edges, is that property and economic interests survive death, while personality interests do not, and should not. The long recognised principle of actio personalis moritur cum persona still reigns, alongside Beverley-Smith's representative comment from the common law world that "reputation and injured dignity are generally of no concern to a deceased person." 177 The most archetypical example of this is the failure of claims in defamation to survive death, despite a few paradoxical post-death criminal defamation laws in the United States. The hostility of the United States to extending the scope of moral rights in the face of international harmonisation on the matter also fits squarely into, and further supports, this pattern of opposition to legal protection of post-mortem pure persona interests.

On the other hand, the civilian tradition seems more sympathetic to post-mortem privacy, through its historical and cultural development of doctrines of personality rights. The German system, in particular, has historically been inclined to recognise the persistence of rights to protect reputation, honour and dignity after death as a fundamental part of its constitutional as well as private law. Meanwhile, the French system, which fathered the notion of droit d'auteur and moral rights, is less convinced on the post-mortem persistence of privacy rights per se, but strongly champions a creator's (or rather his heir's) interest in protecting the integrity of his creation after death, which may well

176 Kasket, supra note 1.

177 See BEVERLEY-SMith, supra note 73. 
operate as a surrogate.

Image rights, of course, are the classic case where a melange of what seems to be a classic property right designed to facilitate commercial exploitation, and a right as deeply entrenched in an individual as their face or fingerprints, baffles both academic and practical lawyers, civilian and Anglo-American alike. ${ }^{178}$ In the United States, home of Hollywood and the celebrity, we see a paradoxical halfway house in the institution of statutory and common law publicity rights, looked upon jealously but cautiously by the English, lacking a firm notion of commercial appropriation of personality yet terrified of creating common law rights of privacy. But publicity rights, even where they are designed to survive the death of the person protected, are still intended, in the main, to protect economic not persona rights, property not privacy. They were introduced to facilitate commercialisation of image, not image itself, and not to protect anything like German notions of dignity or French notions of moral authorship, integrity and attribution. The figures noted above on the sheer value of assets protected by publicity rights, as well as the tendency of publicity statutes to protect only the revenue streams of celebrities (and their assignees) rather than the privacy of non-celebrities makes this plain. Despite the tantalising statement in Haelan that publicity rights were not necessarily conceived of as property rights, that is how they have come to be viewed, albeit with limitations (e.g., the restrictions on post death transmissibility, either absolutely, or in relation to duration).

Finally, European law, coming out of a European tradition of respect for the right to private life in Article 8 of the ECHR, provides, in data protection law, the strongest laws in the world for granting individuals (whether celebrities, non-entities or whatever) control over their personal data. Such rights might be argued to be just what is needed to protect the post-mortem privacy of data subjects in a digital world. The current DPReg process has, for example, given a great deal of publicity to the notion of a "right to forget." 179 (In fact, such a right exists to a very large extent in current DP law, albeit without practical support, since if consent to processing of personal data is withdrawn, then continued processing no longer complies with the provisions of the Directive, and the data subject has the right to demand the data be erased.) ${ }^{180}$ If the soldier in Scenario 0 and the novelist in Scenario 0 had been able to give a standing notice with binding force to the service

178 For examples of the perplexed literature in this field, see supra note 73. For a discussion on how personality rights are difficult for civilian not just common law analysis, see BRUGGEMEIER, supra note 73, ch. 2 (" $[$ P] ublic law recognises fundamental rights . . . Private law provides for subjective rights . . . Civil personality rights do not fit into this dichotomy. They are hybrids, sort of private human rights.").

179 DPReg, supra note 143, art. 17.

180 DPD, supra note 144, art. 12. 
providers in advance of death that they wished their personal data in the form of e-mails or novel to be "forgotten" after their death (i.e., erased by the data controllers who held it, and possibly also "forgotten" by search engines or other parties who linked to it, or shared it), then they would have had an effective way of compelling both heirs and family to respect their post-mortem privacy. Yet, paradoxically, as DP is seen as having its foundation in human rights, it is highly unlikely it will ever be extended to protect post-mortem privacy in this way.

Harbinja ${ }^{181}$ has questioned this human-rights foundation of the EU DP regime asserting that many features of the DPReg reform process actually suggest a shift in the underlying notion of DP from a purely rights-based notion to one more focused on commodification of personal data as property of economic value. As an example, she draws attention to the rhetoric of personal data as the "new oil" of the Internet, and the new proposed right of data portability. Yet, the very notion that personal data has value and is not just to be protected by DP as a privacy right but as a commodity makes it even less likely in terms of realpolitik that DP will be extended to protect the dead rather than reduced to firmly exclude them. In the DPReg process, DP law is already under fire from the multinational and social media Web companies who monetise data as their prime business model; thus, any attempt to increase the scope of personal data protected, rather than diminish it, will likely be met with very short shrift.

So we find that in common law, generally, there is little support for post-mortem privacy, even in light of the imposition of Continental DP doctrine on European common law countries (specifically the U.K and Ireland). On the other hand, paradoxically, common law traditionally supports the doctrine of freedom of testation to a much greater extent than Continental law, which might be seen as enabling the right to control post-mortem privacy. In fact, though, most systems, even in the common law world, do place certain limitations on total freedom of testation. In particular, wishes that may be seen as relating to the personal rather than the economic (such as the desire to be buried or cremated, or to be an organ donor ${ }^{182}$ ), conditional legacies that restrict the autonomy of the surviving heirs ("£1,000 to my wife so long as she never remarries"), and trusts that waste money on pointless vanity without obvious benefit are frequently declared void or ignored on a variety of public policy and societal grounds. ${ }^{183}$ So, a wish that an

181 Harbinja, supra note 1.

182 See infra Part VI.C.

183 See, e.g., Rosalind F. Croucher, How Free is Free? Testamentary Freedom and the Battle between 'Family' and 'Property,' 37 AusTL. J. LEG. PHIL. 9 (2012); see also M. Oldham, Financial Obligations Within the Family-Aspects of Intergenerational Maintenance and Succession in England and France, 60 C.L.J. 128, 128-77 (2001); Robert A. Trevisani \& William Breen, Restrictions on Testamentary Freedom. A Comparative Study and Transnational 
unpublished novel be burnt, or all the e-mails on a server be deleted, might be regarded as personal rather than economic, and thus not within the privilege of freedom of testation. Again, digital post-mortem privacy looks likely to be the loser.

What of civilian law systems? As noted, these are more sympathetic to the idea of the transmission of privacy and personal interests on death, and less rooted in the idea that only economic interests pass on death and can be controlled by the will of a testator. In principle, this sounds good for post-mortem privacy: so if the soldier in Scenario 0, or the novelist in Scenario 0, or even the teenage girl in Scenario 0, had been German, say, would their privacy have been given more respect after their death? Could they have found the tools they needed to control what happened to their personal data, communications or reputation after their death in some variety of personality rights, moral rights or defamation remedies?

Without working through each scenario in detail in this already extensive Article, it seems unlikely. The key problem is that of globalised intermediarisation. In each of our scenarios, the digital assets and thus the post-mortem privacy of the deceased are primarily controlled by contracts with social networks based in the United States, a common law jurisdiction. ${ }^{184}$ (This is of course not inevitable: Germany has, of course, its own social networks, with headquarters in Germany, but in most of Europe it is the large U.S.-based companies that dominate the various parts of the Web 2.0 markets. In December 2012, for example, the top two social networks accessed in Germany were Facebook and Google+, with Twitter in fifth place.) ${ }^{185}$ Thus, the problems we noted in Parts III and IV with intermediary law and practice relating to post-mortem privacy are also likely to affect many

Implications-USA, 15 INT'L LEGAL PRAC. 14, 14-16 (1990); Id. at 20-26; du Toit supra note 170. In Scotland, see the fascinating Presbyterian trusts case of McCaig v. Univ. of Glasgow, [1907] SC 231.

184 Again, there are clear issues here about jurisdiction, applicable law and enforcement. These are touched on briefly in Edwards and Harbinja, supra note $8, \S \mathrm{E}$. We do not have the space to engage with this huge topic here but it is worth hazarding that experience shows that U.S. courts are unlikely to engage with foreign law doctrines they find unpalatable in U.S.-based Internet intermediary cases, even in cases involving foreign nationals or domiciliaries. See, e.g., in re Request for Order Requiring Facebook, Inc. to Produce Documents and Things, 923 F. Supp. 2d 1204 (N.D. Cal. 2012). For a discussion on the debate surrounding foreign court orders seeking access to subscriber IDs on Twitter network in U.S. courts, see Edwards \& Matwyshwn, Twitter (R)evolution: Privacy, Free Speech and Disclosure, IW3C2 WWW 2013 CONFERENCE COMPANION (May 13, 2013), http://www2013.org/companion/p745.pdf.

185 See The German Social Networking Landscape, COMSCORE DATA Mine (Feb. 8, 2013), http://www.comscoredatamine.com/2013/02/the-german-social-networking-landscape/ (last visited May 12, 2013). The fourth and fifth places went to Xing, which appears to be the European equivalent of LinkedIn with $76 \%$ of page views coming from Germany (http://en.wikipedia.org/wiki/XING) and Stayfriends, which appears to be German or at least European-based. See StayFriends.de, WIKIPEDIA (last visited Sept. 24, 2013), http://en.wikipedia. org/wiki/StayFriends.de. 
users based in civilian legal systems. If our soldier, our novelist and our teenager had been German but still using the services of Yahoo!, CloudDrive and Facebook then the same results, at least initially, would have followed.

\section{Against Post-Mortem Privacy: The Organ Donation Dilemma}

So far in this Article, we have supported and argued the view that post-mortem privacy in the digital era is worthy of legal respect, and surveyed what rights users have to control it. At this point, however, it is useful to consider what arguments there are against post-mortem privacy rights. Effectively, such arguments have already percolated through in the survey of comparative personality laws in Part V, since underlying the preference of the common law to see personal interests die with the deceased lie a number of obvious policy concerns.

First, it might be said that protecting the privacy or rights of the dead may conflict with the wishes and needs of the living, which should in the nature of things take priority. More subtly, throughout intellectual property ("IP") literature it is often argued that monopoly rights should not be given over pure information to the detriment of continuing societal interests, and that this is what providing property rights in privacy, transmissible on death, does. In essence, there is a fear that personality rights as transmissible property will confer protection on objects that conventional IP law refuses to protect, namely, facts, ${ }^{186}$ and thus, will potentially restrict access to the public domain, fatally upsetting the balance IP attempts to achieve between incentivising inventions and creativity (whether based on utilitarian theories or Lockean labour theories) and on the other hand, protecting freedom of expression and access to knowledge by preserving a non-proprietary public domain. American writers such as Lemley, ${ }^{187}$ Hammond, ${ }^{188}$ and Besen and Raskind ${ }^{189}$ have thus spoken out strenuously against the propertisation of information, even in contexts where it has many attractions such as providing a "trespass" remedy against website scrapers, ${ }^{190}$ or an earned exclusive scoop in newspapers for "fresh news" they have uncovered. ${ }^{191}$

186 Int'l News Serv. v. Assoc. Press, 248 U.S. 215, 250 (1918) (Brandeis, J., dissenting) ("The general rule of law is, that the noblest of human productions-knowledge, truths ascertained, conceptions, and ideas-become, after voluntary communications to others, free as the air to common use.").

187 Mark A. Lemley, Private Property, 52 STAN. L. REV. 1545 (2000).

188 R. GRANT HAMMOND, QUANTUM PHYSICS, ECONOMETRIC MODELS AND PROPERTY RIGHTS TO INFORMATION, 27.

McGill L.J. 47 (1981).

189 Stanley M Besen \& Leo J. Raskind, An Introduction to the Law and Economics of Intellectual Property, 5 J. ECON. PERSP. 3 (1991).

190 See, e.g., Register.com v. Verio, 356 F.3d 393 (2d Cir. 2004).

191 See, e.g., Int'l News Serv, 248 U.S. at 250 (Brandeis, J., dissenting). 
Perhaps the strongest argument here, in the European context, is that post-mortem privacy might impede freedom of expression. Archives and the historical record would be less complete if personal data were cloaked by privacy post-mortem. Society has a right to know about its history and what art and literature its deceased citizens have left, as a matter of public interest. ${ }^{192}$ Similar debates about the value of privacy and personal data control versus the preservation of the historical record and freedom of speech have haunted the "right to forget" debate in the draft DPReg process (though it is fair to say these arguments have been most diligently pursued by U.S. companies dependent on monetising data, such as Google, rather than home-grown European delegations). ${ }^{193}$

Finally, as already briefly raised above in Part V.D., giving rights in personal data to the deceased creates severe practical problems. ${ }^{194}$ Who is to give the consent of the deceased to use of their personal data - what heirs or representatives, and for how long? Are the heirs required to give consent as they wish, or only in accordance with what they think the wishes of the deceased were? How can conflicts between different family members be resolved, or those between family members and partners or friends? How can service providers know what requests are genuine and which are backed by law? As noted above, presently, service providers request a variety of information from relatives, from newspaper obituaries to death certificates to mere knowledge of the deceased's e-mail address. Scenario 0 illustrates one of the difficulties that might emerge given the rather para-legal laissez faire service-based system that currently exists. Formal recognition of protection of the personal data of the dead would surely require a more rigorous approach to be taken. ${ }^{195}$

A final illustration or exemplar of the difficulties of granting rights to the dead at the possible expense of the living might be drawn from the law and practice of organ donation on death. Here, there has historically been a tendency to prefer the wishes of the living, who

\footnotetext{
192 See Mazzone, supra note 8, at 1652-60.

193 See Peter Fleischer, Foggy Thinking About the Right to Oblivion, Peter Fleischer: Privacy...? (Mar. 9, 2011), http://peterfleischer.blogspot.com/2011/03/foggy-thinking-about-right-tooblivion.html.

194 See Molly Wilkens, Privacy and Security During Life, Access after Death: Are they Mutually Exclusive?, 62 HASTINGS L.J. 1037 (2011).

195 See Mazzone, supra note 8, at 1665-66 (describing varying policies among different websites; for example, Gmail requires a rigorous material production before they will let heirs obtain a deceased's e-mails as opposed to the complete lack of information given by Google regarding how to obtain disposition of a Blogger blog after death and citing LinkedIn as requiring a "verification of death" form to close their LinkedIn profile). Facebook has already had to deal with cases of hoax requests for deletion on death as a kind of "denial of service" attack. See Eric Limer, It's Super Easy To Lock People Out of Their Facebook Accounts by Claiming They're Dead (Updated), GizMODO (Jan. 4, 2013, 4:17 PM) http://gizmodo.com/5973270/its-super-easyto-lock-people-out-of-their-facebook-accounts-by-claiming-theyre-dead.
} 
remain to suffer emotional distress (and to sue hospitals), over the expressed wishes of the deceased. For example, in England, if the deceased indicates a wish to donate (e.g., has a Kidney Donor card in his possession) but his family wishes for him to be buried intact, then generally the wishes of the family take precedence. ${ }^{196}$ In Scotland, interestingly, the law has been changed since 2006 to clearly support the alternative position. ${ }^{197}$ This might be regarded as a victory for rights of post-mortem privacy (or freedom of persona-related testation), but in actuality, the pressing factor has been the societal need for organs in an age of increasingly successful transplantation technology and an aging and unfit population. Currently, in the United Kingdom around a third of the population are on organ donation registries, a rise of around fifty percent over the last five years, but in around forty-five percent of cases, the family has over-ridden the wishes of the deceased and forbade donation. ${ }^{198}$ As a result, donated organs remain at critically low levels.

In the revised Scottish system, "the main principle underpinning the new legislation is that a person's own wishes should be acted on."199 It is clear though that the main driver is not patient autonomy, but organ scarcity. ${ }^{200}$ Nearest relatives will still need to be approached to find out if there are any medical reasons why transplantation should not go ahead, but where the wishes of the deceased (including children aged twelve or over) at the time of death are clear, they cannot be vetoed by the family. In Wales, an even more radical system is in the process of

196 Note that this is a mixture of law and hospital practice reflecting social norms. See HUMAN Tissue AUthority, CODE OF PRACTICE 2: DONATION OF SOliD ORgans OR TRANSPLANTATION đ 96-100 (last revised Mar. 8, 2013), http://www.hta.gov.uk/ legislationpoliciesandcodesofpractice/codesofpractice/code2donationoforgans.cfm?FaArea $1=$ cust omwidgets.content_view_1\&cit_id=674\&cit_parent_cit_id=669. Sally Johnston, NHSBT's director of organ donation explained:

Legally, let us be clear, if you have given consent (for organ donation after death), your family can't overrule it ... . Practically, we have always tended to err on the side of not openly upsetting families. You want families to be proud of their relatives' decision and be happy with it.

James Meikle, Organ Donation: Drive to Prevent Families from Overriding Donor's Wishes, THE GUARDIAN (Apr. 10, 2013), http://www.guardian.co.uk/society/2013/apr/11/organ-donationdrive-prevent-overriding.

197 See Human Tissue (Scotland) Act 2006 (U.K.); see also Human Tissue AuTHORITY, Human TISSUE (SCOTLAND) ACT 2006: A GUIDE TO ITS IMPLICATIONS FOR NHSSCOTLAND 14 (last updated July 2010) [hereinafter Scotland Guidance], http://www.hta.gov.uk/db/ _documents/Information_about_HT_\%28Scotland\%29_Act.pdf.

198 See Meikle, supra note 196.

199 See Scotland Guidance 914 (emphasis added).

200 See NHS Blood and Transplant, TAKING ORgan TRANSPlantation TO 2020: A UK STRATEGY 5 (last visited Aug. 22, 2013), http://www.nhsbt.nhs.uk/to2020/resources/nhsbt organ_donor_strategy_summary.pdf ("The UK can and must do more to save and improve lives through organ donation and transplantation. The NHS still does not support some people who want to donate and more can be done to ensure that donated organs are used."). 
[Vol. 32:1

being adopted, known as "soft opt-out." 201 Persons are given the option of registering as organ donors, or registering explicitly not to be organ donors. If they die making no choice, then hospitals are entitled to regard their omission as giving deemed consent to organ donation. ${ }^{202}$

What is interesting here is that, in the conflict between the wishes of the deceased and the rights of the living, what has proved victorious are the needs of society. What light does this cast on our digital privacy scenarios? In Scenario 0, we might argue that the societal need for a supply of great novels outweighs the qualms of the now shuffled-off deceased. We have seen some support for this in the reaction to stories like those of Nabokov, ${ }^{203}$ and Kafka, who instructed his literary executor, Max Brod, to burn, unread, all of his writings immediately after his death. ${ }^{204}$ Brod, however, did not do this, thereby preserving for posterity classics such as The Trial and The Castle. ${ }^{205}$ If Kafka's novels had been stored on DropBox, or our imaginary CloudDrive, we would be glad if that intermediary had preserved them rather than following instructions to delete. On the other hand, in Scenario 0, we might follow Kasket's line and argue that society increasingly has an interest in the preservation of "virtual mourning places" after death, and that as there is no economic loss to the heirs (and little cost to the intermediary), the societal interest should take precedence over the wishes of the family to shut the site down. In Scenario 0, it is hard to tell what the societal interest is. How do we know that the U.S. soldiers' e-mails will not in the end be more precious to the historical record than our author's novel is to the literary record (there are, after all, many bad unpublished novels in existence). All of these are highly subjective responses and quite different justifications might be adduced (and probably would be by the more Continental-inclined member of the writing team). In short, we are not convinced that societal arguments get us much further here in clearly and objectively finding a way forward for digital post-mortem privacy rights.

\section{CONCLUSIONS AND NEXT STEPS}

We have argued above that although the law, at least in common law systems, has traditionally paid little or no attention to the protection of post-mortem privacy, the new circumstances of the digital world, and in particular the emergence of a new and voluminous array of "digital assets" created, hosted and shared on Web 2.0 intermediary platforms and often revealing highly personal or intimate personal data, require a

201 See Human Transplantation (Wales) Act, 2013 (U.K.).

$202 I d$. at $\S 4$. Certain exceptions to the rule of deemed consent are preserved.

203 See supra note 3.

204 See Lior Jacob Strahilievitz, The Right To Destroy, 114 YALE L.J 781, 830-31 (2005).

$205 I d$. 
revisiting of this stance. If only economic, not personal, interests are protected on death, then notwithstanding the problems identified in Part VI, serious social issues may emerge lacking legal remedies, some of which we sought to illustrate with the scenarios at the start of the Article.

In the early case law we have seen in the United States, such as Ellsworth, lacking a firm theoretical or cultural foundation for postmortem privacy protection in U.S. law, we see the natural emergence of a property-based focus to the resolution of what can quite validly be seen as privacy-related disputes. In the academic and journalistic commentary written about the case as well as the legislative response thereto, the issue has been characterised as being about the digital estate - the rights of the family to inherit their son's e-mails as if they were his hard copy letters - not the pros or cons for the deceased son, or for the family as a whole, of ignoring Yahoo!'s privacy policy. While post-mortem privacy interests were protected in the in re Facebook case, this was mainly an incidental result of protection intended for the living, combined with the desire of the intermediary to protect itself from legal risk. In cases not apparently yet reported via judicial opinion in the United States (or elsewhere in the common law world), such as in Scenario 0 of this Article, control over memorialisation and access to the secrets of the deceased seems to be viewed primarily as an extralegal discussion between an omnipotent intermediary and surviving family, with little attempt, except in the potential future case of Google's Inactive Account Manager, to ascertain what the deceased would have wanted. ${ }^{206}$ It seems likely that in future disputes that impact post-mortem privacy, arguments will revolve mainly around this tension between rights granted to intermediary platforms by their own unilaterally dictated terms of service, and rights of property and administration granted to heirs by the laws of succession and executry. Neither side of this conflict has much time for the privacy of the deceased.

A basic issue here of course (which we have sidestepped till now) is that if the privacy of the deceased is at odds with the economic or personal desires of the heirs, then who is to represent the deceased? In Europe, one answer might be the national Data Protection Authorities ("DPAs") who are already charged with championing the rights of data subjects during life. In the United States, it is much harder to see who

206 As this Article was about to go for review, a new U.S. case on an executor seeking access to e-mails stored with Yahoo! webmail emerged. See Ajemian v. Yahoo!, 12-P-178 (Mass. Ct. App. May 7, 2013). The case seems to be primarily based on a paradigm of e-mails as property (whether chattel, copyright, or both). See Eric Goldman, Yahoo's User Agreement Fails in Battle Over Dead User's Email Account-Ajemian v. Yahoo, TECH. \& MKTG. L. BLOG (May 9, 2013, 8:52 AM), http://blog.ericgoldman.org/archives/2013/05/yahoos_user_agr.htm. Future work will explore this case further. 
[Vol. 32:1

might take this role, though the appointment of some kind of curator ad litem (ad mortem?) seems not impossible. An executor asked to take this role might find herself asked to make impossible choices between her duties to the heirs, to whom she is a fiduciary, and the wishes of the deceased.

In civilian countries, we detect a slightly different pattern. Because of the historic respect for the honour and dignity of the dead as well as for the integrity of the creator as part of the systemic constitutional and human rights culture, there is arguably a greater chance of protection for post-mortem privacy being fitted into existing personality rights discourse, as opposed to being recast as a question of property law or simply disregarded. (This should not however be overstated: as seen above, even France has been reluctant to develop a notion of postmortem privacy rights per se.). This bears more investigation, and we hope to look at emerging Continental practice in this area in our further work. But as noted above, many disputes involving the digital assets and post-mortem privacy of nationals of civilian legal systems are in any case likely to be fought, whether in or out of court, according to U.S. rules.

Future work might consider what solutions, if any, there might be to the problem of protecting post-mortem privacy in the common law world. One obvious solution is legislation. The Ellsworth case inspired a large number of laws to be passed fairly rapidly, protecting the rights of heirs and their legal representatives. Additional laws could also be passed considering the privacy rights of the deceased. It seems likely, however, that the living have more of a lobby as voters than the dead.

The other avenue for regulation is contract (and contract that influences code). As noted in our survey in Part 4 above, the Web 2.0 marketplace currently mainly lacks contractual norms helpful to postmortem privacy, though pace the Yahoo! policy which led to the Ellsworth dispute. Google's Inactive Account Manager, which can be seen as reading into the contract, via code, terms about disposal of data on death, is a positive step forward; however, too much celebration has to be forestalled since it is known that many users, with customary inertia, will still not make use of its facilities. As in the organ donation debate, the question then might be what inference should be drawn from silence. If Inactive Account Manager is set by default to "delete all my stuff on death" then we have an effective requirement for positive optout of post-mortem privacy. If, however, it is set to a default of "do nothing when I'm dead," unless altered, which appears to be the case, then effectively we have created a need to opt in to post-mortem privacy. ${ }^{207}$ As with all discussion of social media contracts, part of the

207 See Jay P. Kesan \& Rajiv C. Shah, Setting Software Defaults: Perspectives from Law, 
problem is the well-researched point that conventional market competition is failing to produce a range of options for consumers (where, for example, is ZombieTalk, the social network that cares about you by default when you are dead?).

One final thought might be that the above discussion has perhaps identified two notably different types of post-mortem privacy claims. One might be termed "negative post-mortem privacy" - the right to keep matters secret after death. In some ways this corresponds to the classic Warren and Brandeis conception of privacy as the "right to be let alone." 208 A second type of claim might however be termed "positive post-mortem privacy" - the right to control one's image or brand after death. This latter concept arguably fits far better into the common law property paradigm, as well as the civilian notion for respect for dignity and honour after death, and thus is much more likely to command legal protection within the frameworks we have analysed. Indeed, one could easily imagine it protected under some of the existing U.S. publicity statutes. On the other hand, "negative" post-mortem privacy seems to fare badly in both the common and civilian world, judging by the small sample of the extra-legal results for Nabokov and Kafka and the lack of enforceable defamation and confidence remedies after death. Is this a real dichotomy? Is there a difference worth enshrining between keeping a secret and promoting an image? If so, is it one we want to respect? Or is there an argument on instrumental grounds that secrets are as worthy of protection as image? We hope also to return to this in further work.

Computer Science and Behavioral Economics, 82 NOTRE DAME L. REV. 583 (2006) (discussing the power of defaults in the online world).

208 Samuel Warren \& Louis Brandeis, The Right to Privacy, 4 HARV. L. REV. 193, 193 (1890). 